\title{
La reducció de la jornada a trenta-cinc hores*
}

\author{
Isabel Calbet \\ Sílvia Garriga \\ Xavier Lombarte
}

\section{Resum}

El present estudi presenta una visió general sobre el debat actual entorn a la reducció de la jornada màxima legal de treball com a mesura de creació d'ocupació a Espanya i tracta de ponderar els avantatges i desavantatges d'una intervenció pública que redueixi la jornada laboral a trenta-cinc hores setmanals. I qual ment, s'analitzen altres instruments alternatius a partir dels quals obtenir l'optimització del temps de treball i la creació d'ocupació, amb especial esment de la distribució irregular de la jornada, la reducció de les hores extres i el foment del recentment modificat contracte a temps parcial. Finalment, s'aporta un estudi economètric a partir del qual valorar els efectes de l'esmentada reducció sobre la competitivitat, la inflació o la creació d'ocupació, atès que és necessària la intervenció d'altres instruments per arribar a una reforma global i integrada.

Paraules clau: jornada, temps de treball, ocupació, hores extres, contracte a temps parcial, horari.

Abstract. The reduction of the working hours to thirty-five hours for week

This piece of research gives a general view on the current debate about the reduction of the maximum legal working hours as a way of creating employment in Spain, and also highlights the advantages and disadvantages of public control to reduce the working week to 35 hours for week. Likewise, it analyses other alternative tools in order to improve the working time and the creation of employment, focusing on an irreegular distribuion of the working hours, a reduction on the overtime and encouraging part-time contracts. Lastly, it is an econometric study research to rate the effects of the above mentioned reduction on competitivity, inflation or creation of employment. It is undeniable that a control of other instruments is needed to achieve a global, integrated reformation.

Key words: working hours, working time, employment, overtime, part-time contracts, horary.

* Aquest treball s'ha desenvolupat en el marc de l'assignatura D ret del Treball II, de segon curs de la diplomatura de Relacions L aborals, impartida per la D ra. Esther Sánchez Torres. 


\section{Sumari}

$\begin{aligned} \text { Presentació } & \text { Postures dels agents socials } \\ \text { Introducció } & \text { M odel economètric d'efectes de } \\ \text { Jornada pactada } & \text { la reducció de la jornada a curt termini } \\ \text { Com procedir a una reducció } & \text { Conclusions } \\ \text { de la jornada? } & \text { Bibliografia }\end{aligned}$

\section{Presentació}

La reducció de la jornada de treball és un tema que avui dia s'està plantejant des de molts àmbits com una possible via de solució al greu problema d'atur que presenta el nostre país. Tot i això, aquesta proposta no és pas exclusiva d'Espanya ni tampoc hi té origen, sinó que s'ha plantejat en molts altres països comunitaris com a forma de resposta a l'atur creixent que s'està donant en el context europeu.

La raó per la qual aquesta proposta es dóna a Europa i no en altres llocs és el fet que la incidència de l'atur és força més elevada en els països de la U nió Europea (amb una mitjana l'any 1994 de l'11\% de la població activa, que a Espanya va arribar al 24,2\% el mateix any) que en altres països com els Estats Units (on podem considerar que només hi ha atur friccional) o el Japó. Per aquest motiu, cal buscar possibles solucions al problema. Amb aquesta finalitat, la reducció de la jornada ja s'ha posat en funcionament en determinats Estats europeus, com Alemanya, i és a punt de dur-se a terme en d'altres com França o Itàlia.

Per tant, el nostre objectiu és determinar la viabilitat del'aplicació d'aquesta mesura en el nostre país quant a la creació d'ocupació. Així, cal analitzar la seva efectivitat potencial i real i la possibilitat o necessitat que vagi acompanyada d'altres mesures. Considerem que un tema d'aquesta rellevància és sobradament mereixedor d'un estudi al respecte.

\section{Introducció}

La reducció de la jornada de treball ha estat i avui dia encara és una de les reivindicacions sindicals més importants, tot i que hi ha hagut i hi ha una forta oposició a aquest procés de reducció per part de la patronal i una constant històrica que s'ha anat produint en els darrers cent anys.

A Espanya les successives limitacions i disminucions de la durada de la jornada de treball es remunten ja a la meitat del segle passat i es presentaven com una de les primeres manifestacions de l'intervencionisme estatal en les relacions laborals $s^{1}$, en base a raons tan humanitàries (defensa física i moral de l'obrer)

1. L'any 1855 es promulgà el primer projecte de llei de restricció de la jornada, tot i que era referida tan sols al treball dels nensi dels joves. Aquesta llei, però, no significà l'inici d'un procés legislatiu orientat cap a la reducció de la jornada, ja que aquesta restava desplaçada del 
com econòmiques (presència de rendiments decreixents). El procés, això no obstant, fou lent, per la resistència patronal, la presència de tesis econòmiques que derivaven necessàriament de la reducció de la jornada una gran reducció del benefici de les empreses i el relatiu desinterès obrer fruit del caràcter ludista dels primers conflictes laborals. A més, es tracta d'un procés socialment limitat en la mesura que, sota la funció tuïtiva de la primera legislació, sadreçava als col-lectius més desfavorits?2.

Amb l'entrada del nou segle s'introduïren una sèrie de normes que donaran com a fruit, finalment, l'obtenció de la révindicació de la reducció de la jornada laboral a vuit hores 3 .

centre de les lluites socials. Allò que importava era la consolidació de les organitzacions obreres i la lluita contra la màquina.

El silenci es trencà a final dels anys seixanta, quan les associacions obreres, ja consolidades per la Primera Internacional (la qual inicià la reivindicació de la jornada de vuit hores), es van Ilançar cap a una intensa activitat política. Així va ser com sorgí el projecte de llei presentat per M anuel Baena l'any 1872, referit al treball dels menors, que no prosperà.

La llei de protecció dels nens, de 24 de juliol de 1873, coneguda com a Llei Benot, regulà finalment la jornada laboral dels menors. Tot i que no existeixen comprovacions exactes sobre l'acompliment d'aquesta llei, la literatura de l'època fa pensar que aquest fou escàs.

2. La Primera República intentà, això no obstant, anar més lluny. S'efectuà el primer projecte de llei que abastava tota la població, amb una jornada de nou hores diàries per a qualsevol tipus d'activitat. Però, com altres projectes, no arribà a aprovar-se a causa dels canvis de govern.

Tot i la manca de tractament per part de la llei, es continuà reivindicant la reducció de la jornada, en un context d'expansió econòmica produïda per la febre de l'or entre 1876 i 1886, que havia provocat un increment de la demanda de força de treball.

Ja en certs sectors es preveia una jornada inferior a la general.

Algunes dades procedents d'un estudi real itzat l'any 1884 per la Comissió de Reformes Socials sobre la situació de la classe obrera pel que fa al nombre d'hores treballades en l'època indiquen clarament la ineficàcia de les lleis precedents, generada bàsicament per una manca de control.

Cap a la dècada dels noranta, el govern torna a fer una altra sol-licitud a la Comissió de Reformes Socials per saber I'opinió sobre la jornada de treball, i els resultats són molt clars: totes les associacions obreres es pronuncien a favor de la reducció de la jornada, mentre que les organitzacions patronals s'hi oposen considerant que la regulació de la jornada és un atemptat a la llibertat de contractació i inadmissible, tenint en compte les repercussions que tindria sobre el conjunt del sistema econòmic. Aquesta concepció s'anirà repetint al llarg dels anys i encara perdura en els nostres dies.

Una altra modificació en l'horari laboral per als nens es produí a través de la Llei de 13 de març de 1900. Aquesta llei fou més respectada que l'anterior, tot i que encara faltava un organisme d'inspecció que garantís l'acompliment d'allò legislat.

3. La primera fou la R.O. d'11 de març de 1902, en què es fixa una jornada màxima de vuit hores/dia per als obrers al servei de l'Estat, introdueix el concepte d'hores i la reglamentació del descans, i comença a regir la llei de descans dominical el mes de setembre de 1904, com a conseqüència d'una sèrie de vagues generals en aquest sentit van pressionar en els anys precedents. Vegi's el paral·lelisme amb la situació actual, en què molts ajuntaments han començat a reduir la jornada, prenent una iniciativa quan encara és un tema que s'està debatent. N o obstant aixó, sovint la mesura sadopta més per qüestions de caire polític que per raons de qualitat de vida i creació d'ocupació. 
En la mateixa línia que el Conveni número 1 de l'O IT, la Llei de jornada màxima (promulgada com a D ecret el dia 1 de juliol de 1931 i elevada a Ilei en data 9 de setembre de 1931) generalitzà la jornada màxima diària de vuit hores, computable setmanalment sempre i quan no se superés el límit de nou hores diaries 4 . Es preveu així mateix una limitació quant al nombre d'hores extraordinàries (cinquanta hores extres/mes i cent vint hores extres/any).

D urant la Segona República començà a considerar-se el còmput de la jornada en termes setmanals i s'inicien les discussions al voltant de la instauració de la setmana de quaranta hores. Amb aquest objectiu, la Sociedad para la

L'any 1912, amb sis anys de retard, Espanya s'adhereix al Conveni de Berna, que prohibeix el treball nocturn de les dones a les fàbriques $i$ tallers. El 1913 es produeix també una limitació en la jornada a la indústria tèxtil.

L'any 1917 s'entra en l'època de la Restauració, que durarà fins al 1923. Es produeix una substitució del sistema pietista per un model normatiu anomenat «modern» pels seus plantejaments ideològics, per la forma d'interpretar l'acció del moviment obrer i, sobretot, perquè intenta afrontar les causes de la qüestió social.

Així mateix, es dóna un fort intervencionisme de l'Estat. La tensió anava en augment a causa de la crisi política i econòmica (sobretot des del final de la Primera Guerra M undial), que generava atur i inflació, mentre les classes capitalistes prosperaven. És una època de reformes laborals, principalment degudes a l'avanç del moviment obrer. L'any 1918 el PSO E ja demanava la jornada màxima legal de vuit hores/dia (de fet, la reducció de la jornada màxima a quaranta hores/setmana fou una de les mesures que adoptà el primer govern socialista en la seva primera legislatura), mentre que els anarquistes anaven més enllà i reclamaven una jornada de sis hores/dia i les vacances anuals pagades. En aquest mateix any apareix una normativa per a regular la jornada màxima en la dependència mercantil.

Finalment, el 1919 el comte Romanones promulga el R.D. de 3 d'abril de 1919, que estableix una jornada màxima diària de vuit hores, tot i que preveu moltes excepcions a aquesta norma. En aquesta llei es tenen en compte les propostes de l'I nstituto de Reformas Sociales en el seu estudi «D uración de la jornada en los distintos oficios y términos demográficos de España» i els avenços europeus en la reducció de la jornada, mentre que les excepcions es determinen tenint en compte els criteris de competència internacional, ja que en aquells moments Espanya s'havia trobat en una etapa d'expansió i obertura exterior, aprofitant la Primera Guerra M undial per a cobrir els mercats que abans eren nodrits pels països bel-ligerants. N oti's que la competència internacional és una raó al·legada en tots els països per part de les organitzacions patronals i els governs i que encara perdura avui dia, amb més força si fos possible, a causa de l'increment del pes del sector exterior en els països desenvolupats. L'acompliment real de la jornada de vuit hores en els anys compresos entre la seva promulgació i la proclamació de la Segona República, deixa molt que desitjar. El mateix any 1919 es regulen jornades especials, com la jornada mercantil dels dependents de perruqueria i barberia i la jornada màxima al sector de la construcció.

D urant l'exercici de 1920 apareix una Reial 0 rdre de desenvolupament del R.D. de 1919 i també una altra Reial O rdre que estableix les excepcions. Posteriorment, la ratificació per Espanya del Conveni número 1 de l'O IT (signat el 1919) el dia 1 de maig de 1931 porta a l'aplicació dels límits de vuit hores diàries i quaranta-vuit hores setmanals per a les empreses industrials.

4. No obstant això, també aquí trobem excepcions respecte als límits per a certs col·lectius (directius d'empreses, empleats de servei domèstic, porters, guardes i pastors), possibles ampliacions dels límits màxims (agricultura, transports i serveis sanitaris) i reduccions del límit màxim general en el cas de les mines. 
Reforma Social organitzà l'any 1933 una sèrie de reunions per la reducció de la jornada. Si resumim els punts de vista dels treballadors, de la patronal i dels tècnics independents es pot veure que5:

\section{Per part dels treballadors s'afirma que:}

- La reducció de l'horari de treball és necessària per a eliminar l'atur.

- La solució a l'atur no és un subsidi, ja que aquest crea un procés inflacionista.

- Els patrons al·leguen que, si es redueix la jornada, es produeix inflació, cosa que només és certa si no estan disposats a veure reduir els seus beneficis.

5. Paran que, R. La semana de treinta horas. M adrid: Colección Beta, 1969.

Resulta curiós observar que algunes d'aquestes opinions no són gaire diferents de les exposades actualment pels agents socials. Els sindicats demanen una reducció de la jornada amb la finalitat de crear ocupació, tot i que actualment no es planteja l'eliminació de l'atur tal i com es deia l'any 1933, perquè la incidència d'aquest és actualment molt més elevada. N o obstant això, el plantejament d'aquest argument l'any 1933 era innovador, ja que fins aleshores els objectius se centraven en aspectes de qualitat de vida i salut laboral, qües tió que resta aquí en un segon pla.

Pel que fa als subsidis d'atur, també s'ha debatut sobre la seva conveniència o no, però allò que és indubtable és que han suposat un avenç important cap a la creació de l'Estat del benestar.

L'automatisme entre increment de costosi increments de preus, que ja al eshores propugnaven els empresaris, encara avui és certament criticable, ja que suposen que no hi ha d'haver erosió dels marges, és a dir, que el preu ha d'augmentar necessàriament en la mateixa proporció que els costos. Tenint present que la reducció de la jornada és una mesura que ha d'afavorir el conjunt de la societat, no és coherent que sabaixin els sous i que els empresaris vulguin mantenir el mateix marge de benefici. Cal un sacrifici de tots i no només un «repartiment de l'atur».

Pel que fa al tema del dumping, el que es planteja és que al tres països amb costos laborals inferiors poden produir a cost més baix, cosa que els permet vendre a un preu menor amb el mateix marge de benefici i que faria que la demanda interna del nostre país es cobrís amb productes importats, més barats que els nacionals. Parlar de la possibilitat de dumping és avui dia bastant més evident i important que en aquella època, a causa del descens dels aranzels i de les barreres no aranzelàries, la globalització dels mercats, la deslocalització de la producció de les empreses dels països desenvolupats, etc.

Resulta curiosa l'afirmació dels empresaris que quan la reducció de la jornada és necessària la fa automàticament l'empresari. Això només es pot afirmar si entenem per necessària la reducció de jornada corresponent a la situació en què hi ha un descens en la demanda del producte, la qual cosa provoca que no es necessiti tanta mà d'obra i que la reducció de la jornada permeti a l'empresari estal viar costos laborals, a costa d'erosionar les rendes reals dels treballadors.

Un altre fet que resulta interessant mencionar és la idea que l'atur és fruit del subconsum. Per tant, la solució consisteix en el creixement de l'economia (el qual requereix un increment del consum). Si tenim present que, per als empresaris, és inviable la reducció de la jornada sense disminuir el salari, es veu la mesura com a negativa, ja que el descens dels ingressos dels treballadors podria fer reduir el consum.

Per tant, podem afirmar que, efectivament, moltes de les idees propugnades avui dia tenen un origen bastant anterior. 
2. Per part dels empresaris es promulga que:

- Reducció de la jornada significa increment de costos, inflació i més atur.

- La reducció de la jornada és la rutina de la petita empresa.

- Si es reduís la jornada, els països de l'estranger farien dumping.

- Q uan la reducció és necessària, l'empresari ja ho fa automàticament.

- L'atur és fruit del subconsum, no de jornades excessives.

3. L'opinió dels tècnics independents es concreta en:

- El problema prové de la mala organització del crèdit, que no acudeix on realment fa falta.

- La manca de diners implica un subconsum que porta a un descens de la producció 0 a un decrement dels costos, cosa que es tradueix en atur.

- La reducció de la jornada, per tant, no és la solució a l'atur, sinó que cal reestructurar el crèdit. Per tant, cal pronunciar-se en contra de la reducció de la jornada.

En els exercicis següents es promulguen altres normes no específiques de la regulació de jornada màxima però relacionades amb el temps del treball, com la Llei de 13 de juliol de 1940 (reguladora del descans setmanal, on es preveu el descans dominical).

La Llei de contracte de treball de 1944 reconegué als treballadors el dret a unes vacances retribuïdes de set dies, xifra que s'augmentà posteriorment a través d'ordenances i reglamentacions de Treball.

L'O rdre del M inisteri de Treball de 13 de desembre de 1961, que estableix el descans intermedi de trenta minuts en les jornades continuades (cosa que redueix la jornada efectiva a unes quaranta-cinc hores setmanals).

D e nou es torna a intervenir directament sobre la durada de la jornada amb la Llei de relacions laborals de 19766, però l'evolució definitiva de la regulació del temps de treball troba el seu punt d'inflexió el 5 de gener de 1980, quan la U GT i la CEO E subscrigueren I'Acord M arc Interconfederal, que preveia una reducció de jornada progressiva, passant de 1.980 hores el 1980 a 1.880 hores el 1982 i es donava un fort impuls a la utilització d'un mòdul de còmput anual, cosa que permet una reordenació del temps de treball que possibilita més flexibilitat.

6. En el seu article número 23 estableix una jornada màxima ordinària de quaranta-quatre hores/setmana (vegi's que es canvia el mòdul de referència. Les hores extraordinàries també es regulen de forma una mica més favorable als treballadors (els màxims s'estableixen en dues hores/dia, vint hores/mes i cent vint hores/any). No obstant això, cal destacar que les excepcions previstes en la llei de 1 de juliol de 1931 no es deroguen.

També l'any 1976 es regulen per R.D. les jornades de tres col-lectius concrets: els treballadors a torns en el comerç, els transports per carretera i ferrocarril i els treballadors del mar.

Tot i el màxim de quaranta-quatre hores/setmana, els convenis col·lectius ja estaven negociant jornades una mica inferiors a partir de 1978. 
També I'any 1980, amb la promulgació de la Llei de l'Estatut dels Treballadors de 14 de març s'estableix una reducció de la jornada, quarantatres hores setmanals en jornada partida i quaranta-dues hores setmanals en jornada continuada i limitació de les hores extraordinàries a dues hores/dia, quinze hores/setmana i cent hores/any.

Així, l'efecte combinat de l'AM I i de l'ET portà a la jornada anual pactada al voltant de les 1.880 hores/any, quan la Llei 4/1983 de 29 de juny, de nou redueix la jornada màxima legal fins a les quaranta hores/setmana, reestablexx el descans de quinze minuts per a les jornades continuades $i$ incrementa les vacances mínimes fins als trenta dies, d'aquesta manera s'ha arribat actualment a la jornada màxima anual de 1.826 hores i 27 minuts? .

La integració d'Espanya a la C omunitat Europea va comportar la necessitat d'adaptar la nostra legislació als processos de convergència i redefinir-la tenint en compte els requeriments de competitivitat derivats de la globalització de l'economia.

En aquest context l'Estatut dels Treballadors de 1994 va tenir una clara voluntat flexibilitzadora, ja que va reduir la normativa estatal al mínim necessari per a una correcta protecció del treballador, i va obrir amplis espais a l'autonomia collectiva i, en algun cas, a la individual.

En conseqüència, la nostra legislació ha renunciat a establir normativament la jornada ordinària, entenent que ha de ser determinada pels propis interessats, ja sigui per negociació collectiva o per contracte de treball. El joc entre les dues fonts reguladores és condicionat per l'article 3.1.c de l'ET, article del qual es desprèn que els possibles pactes per contracte poden millorar la regulació establerta en conveni col·lectiu, però mai empitjorar-la.

L'article 34 ET estableix que la durada de la jornada de treball serà la pacta da en conveni o contracte, però que la durada màxima de la jornada ordinària de treball serà de quaranta hores setmanals de treball efectiu de mitjana en còmput anual. Aquest límit ja existia amb anterioritat a l'Estatut dels Treballadors de 1994, però la nova redacció matissa precisament que el límit màxim será «en mitjana de còmput anual», i no setmanal8.

Així, tenim que l'ús del còmput anual com a referent serveix per a aconseguir més flexibilitat en la distribució del temps de treball. També en aquesta línia de flexibilització l'article 34.3 ET estableix un límit superior de nou

7. Posteriorment, el Reial D ecret Llei $1 / 1986$ de 14 de març establí el màxim aplicable en la qüestió de les hores extraordinàries en vuitanta hores/any, i es van suprimir els límits diari i mensual.

8. L'absència d'aquesta referència en l'Estatut dels Treballadors de 1980 podia suscitar el dubte de si en fixar aquest màxim hi havia o no una referència també a la distribució irregular de la jornada, de forma que no quedava clar si es prohibia o no que en algunes setmanes es treballés més de quaranta hores i en altres menys de quaranta hores (per exemple, que en una setmana es treballessin quaranta-cint hores i en la següent se'n treballessin trenta-cinc per a compensar). No obstant això, el propi Estatut dels Treballadors de 1980, en l'article 34.2, donava la possibilitat que els convenis regulessin jornades anuals, respectant el límit de nou hores diàries de l'article 34.3 ET, però sense exigir el respecte de la jornada setmanal. Així doncs, la jornada irregular ja era permesa en còmput setmanal. 
hores diàries que és disponible per conveni col-lectiu, sempre que es respecti el límit de descans entre jornades de dotze hores. Aquest límit de nou hores ja existia en l'article 32.2 de l'Estatut dels Treballadors de 1980, però la vigent regulació hi introdueix una profunda modificació, ja que fins al 1994 ens trobàvem davant d'un límit imperatiu, que establia que qualsevol hora que es realitzés per sobre de les nou hores no només havia de ser retribuïda com a hora extraordinària, sinó que, com la jurisprudència confirmava, tenia plenament aquest caràcter amb independència de la jornada màxima setmanal o anual que es treballés. Actualment, en canvi, el límit juga en relació amb la distribució irre gular (art. 34.2 ET) i amb la consideració d'hores extraordinàries (art. 35.1 $\mathrm{ET}$ ), però no com a precepte de dret necessari, sinó amb caràcter parcialment dispositiu, i és, per tant, susceptible de modificar-se per conveni col·lectiu o per pacte a nivell d'empresa entre l'empresari i els representants dels treballadors, amb l'única limitació de respectar també els descansos entre jornades i el descans intersetmanal ${ }^{9}$.

Consegüentment, la regulació de la jornada en el dret espanyol és fruit de l'articulació de la regulació legal i de la convencional. Els convenis col-lectius regulen aspectes com el nombre d'hores que cal realitzar, les vacances, les hores extraordinàries o la distribució de la jornada, entre d'altres. D e fet, en la majoria de convenis col-lectius es tracta el temps de treball de forma diferenciada respecte a altres matèries, la qual cosa és un indici de la seva importància.

Alguns dels punts més importants de la regulació dels convenis col·lectius sobre jornada i temps de treball en general10 són els que es tractaran a continuació.

\section{Jornada pactada}

Aspectes regulats en els convenis

La gran majoria de convenis col lectius estableixen una jornada màxima inferior al límit legal, tot i que n'hi ha que estableixen explícitament la jornada

9. Si el treballador té menys de divuit anys, I'article 34.3 ET hi afegeix el límit màxim de vuit hores diàries, inclosa la formació. Si es treballa per a diversos empresaris el còmput ha de tenir en compte les hores realitzades amb cadascun d'ells. D efet, el règim previst en l'ET és aplicable excepte si hi ha un règim més favorable derivat de conveni col'lectiu o contracte. En la regulació anterior (ET'80) no es diferenciava a efectes de jornada diària màxima entre menors i majors de divuit anys, enfront de la diferència establerta actualment.

D e fet, aquesta inexistència d'un autèntic màxim de jornada setmanal planteja problemes quant a la salut laboral, ja que la perllongació de la jornada diària i setmanal és un clar factor potenciador dels riscos en el treball i dels accidents laborals. Precisament per aquest motiu, la D irectiva 93/104 CE contempla un límit màxim de quaranta-vuit hores, incloses les hores extraordinàries, per un període de set dies. No obstant això, pel fet de trobar aquesta regulació en una directiva i no en un reglament, no és aplicable directament a Espanya, sinó que caldria la seva incorporació a la llei, cosa que no es dóna actualment.

A més, s'ha de tenir en compte que la jornada màxima no podrà ser excedida pel fet que es treballi en diferents llocs o centres de treball per a un mateix empresari.

10. Basat en un mostratge de seixanta-cinc convenis de 1997 i en Tiempo de trabajo. 
màxima legal, d'altres que no diuen res al respecte (i, per tant, cal entendre que la jornada establerta és la màxima legal) i d'altres que es remeten a convenis d'altres àmbits.

És habitual que molts convenis estableixin una jornada diferent d'acord amb la jornada (continuada o partida), la categoria professional (normalment menys hores a superior categoria per a compensar el temps de disponibilitat del treballador cap a l'empresa), la nocturnitat o no (en molts convenis es pacta una jornada menor per als treballadors nocturns, en atenció a qüestions relacionades amb la salut del treballador), etc.

Pel que fa a la voluntat de reduir la jornada, en molts convenis amb vigència superior a l'any es pot observar que es va reduint progressivament la jornada (en còmput anual), tot i que les reduccions pactades no acostumen a ser gaire significatives.

La forma de fixar el nombre d'hores difereix entre els convenis, de manera que hi trobem des de la regulació en còmput anual fins al còmput setmanal (irregularitat molt menor), passant pel mensual.

\section{Evolució del nombre d'hores pactades}

La jornada mitjana anual pactada a I'Estat espanyol en els convenis col-lectius des de 1982 fins a 199711 ha seguit una tendència a la reducció paulatina fins al 1992 i, a partir de la crisi que sesdevé en aquest any, hi ha un petit augment.

A la figura 1 podem observar que aquesta reducció té lloc de forma molt més acusada entre 1982 i 1984, amb un descens d'aproximadament unes vuitanta hores, fet bàsicament explicat per l'entrada en vigor de la Llei 4/1983 que establia el límit actual d'hores de treball (1.826 hores i 27 minuts en còmput anual). Q ueda patent en el gràfic que els convenis de l'any 1983 registren una mitjana superior a aquesta jornada, això és així perquè en el moment de promulgació de la llei molts convenis ja estaven pactats.

Les mateixes dades, però referides a convenis d'àmbit d'empresa, il.lustren la mateixa tendència cap a la disminució de la jornada i cap a la seva estabilització, en els darrers anys. Si comparem els convenis d'àmbit empresarial amb els d'àmbit supraempresarial, observem que les empreses que tenen conveni propi realitzen menys hores que les que es regeixen per un conveni col·lectiu supraempresarial. Aquesta mateixa conclusió es pot extreure a partir d'un estudi realitzat entre grans empreses ${ }^{12}$ del nostre país ${ }^{13}$.

11. Segons I'Estadística de Convenios Colectivos.

12. S'entén com a gran empresa aquella que té més de cinc-cents treballadors.

13. La negociación colectiva en las grandes empresas ( $M$ inisteri d'Economia i H isenda). Agafant un període que comprèn des de 1987 fins a 1995, s'observa que la jornada pactada ha anat minvant, amb una tendència els darrers anys, sobretot a partir de 1991, a fer-ho de forma més lenta. Es passa de 1.771 hores/any pactades el 1987 a 1.729,1 hores/any el 1995. 


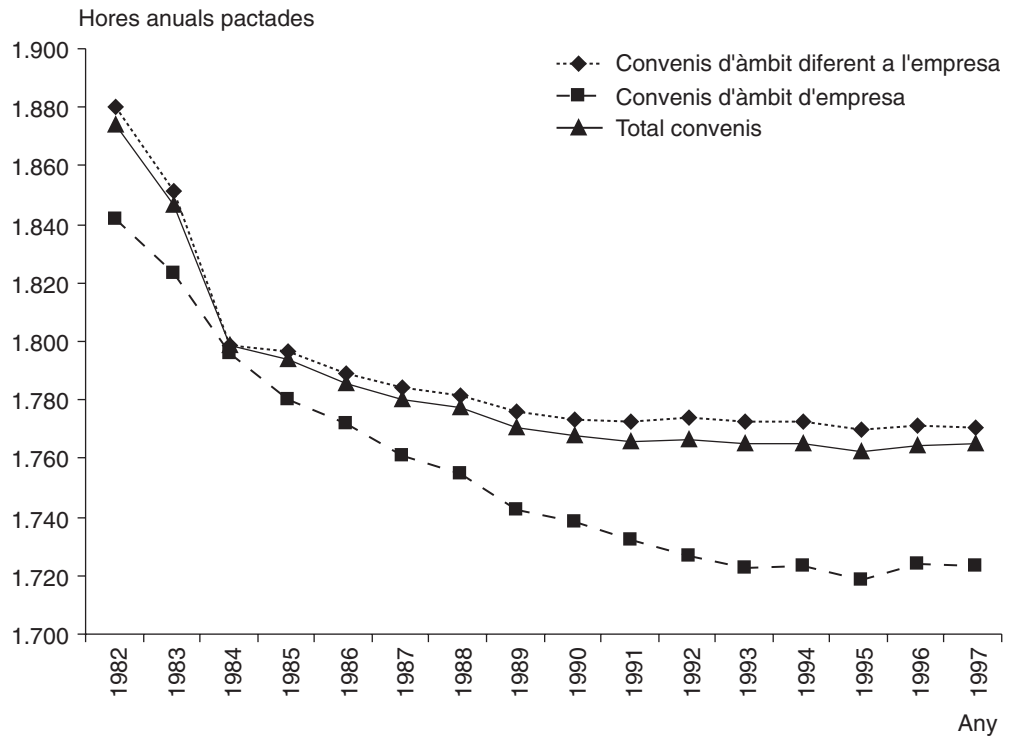

Figura 1. Evolució del nombre anual d'hores pactades en els convenis col·lectius (1982-1997). Total convenis, sense el sector agrari.

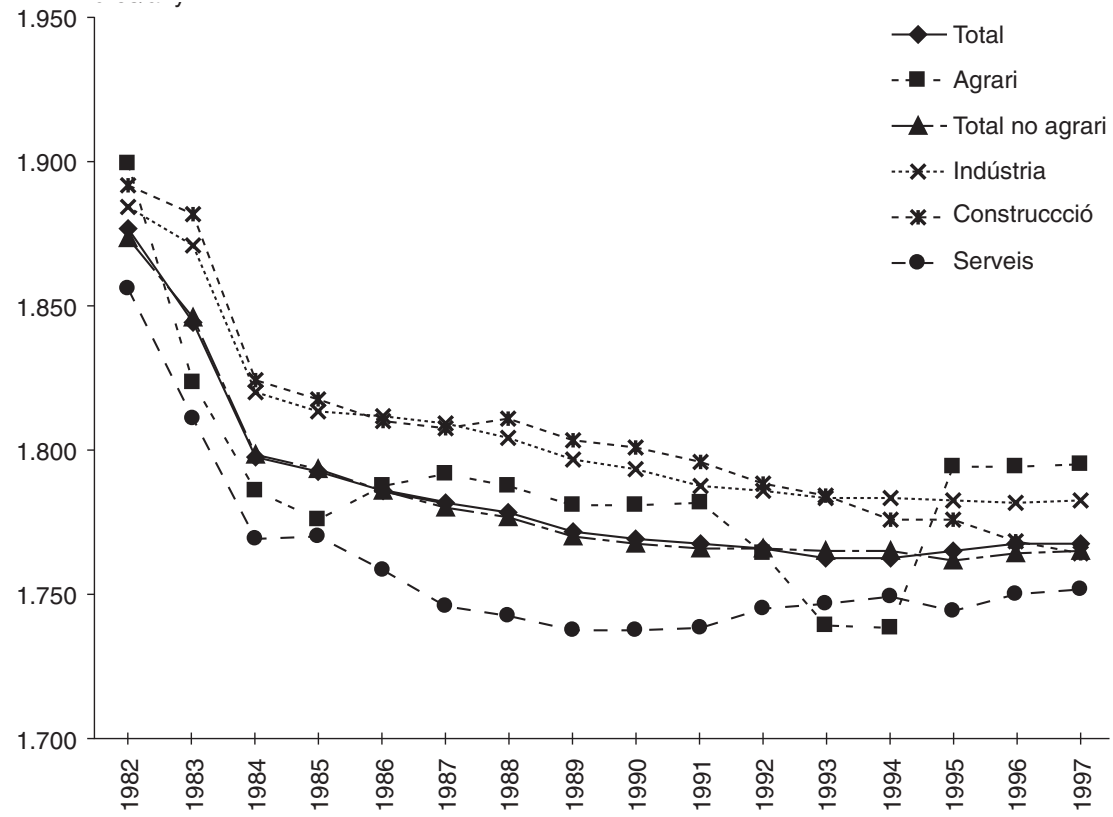

Figura 2. Evolució del nombre anual d'hores pactades en els convenis col·lectius per sectors (1982-1997). 
És possible que aquestes diferències es deguin bàsicament a dos factors:

- Més implantació i pes dels sindicats a l'empresa.

- Més possibilitat d'accés a tecnologies que permeten una productivitat més elevada i, per tant, jornades laborals més curtes.

En analitzar les diferències segons els sectors d'activitat (agricultura, indústria, construcció i serveis) s'observa aquesta mateixa tendència descendent. L'any 1982 el sector agrícola era el que es trobava en un nivell més alt, amb una jornada en comput anual de 1.900,1 hores, seguit per la construcció, amb una jornada de 1.892,4 hores, xifres que contrasten amb el sector serveis, el qual es trobava en una mitjana prou inferior de 1.856,8 hores.

El sector agrari és potser el que presenta una tendència menys clara. La gran disminució en aquest sector es dóna entre els anys 1991 i 1994 (amb una disminució de 43 h) per a tornar després a nivells superiors als del 1984. Per tant, el principal causant del descens és la reducció efectuada com a conseqüència de l'entrada en vigor de la llei de 1983 referent a la jornada.

A la indústria es dóna un descens lent però continuat a partir de 1984. S'observa, això no obstant, un lleuger minvament del ritme de descens de la jornada anual en els darrers exercicis.

Al sector de la construcció es produeix un descens constant i no s'hi observa la desceleració en els darrers anys, tal com es dóna en els altres sectors. No obstant això, si mirem l'evolució de la jornada pactada en els convenis empresarials, es pot apreciar un clar increment en els inicis de la dècada dels noranta, a causa de l'empenta de la construcció que portaren els J ocs O límpics de Barcelona i també l'Exposició U niversal de Sevilla, tots dos esdeveniments cel ebrats l'any 1992.

El sector serveis és el que presenta una jornada més baixa durant tot el període. Això pot ser degut al fet que abasta alguns sectors (com, per exemple, ensenyament, administracions públiques, etc.) en què la jornada ha estat tradicionalment baixa o perquè els serveis es caracteritzen per estar sotmesos a menys competència internacional que altres sectors com la indústria (cosa que provoca menys pressió sobre els beneficis i que fa, per tant, que hi hagi hagut un marge de maniobra més gran en el tema de durada de la jornada, fet que ha possibilitat un descens més elevat).

A partir del gran descens del 1984, presenta una tendència a la baixa. Aquesta tendència es frena vers el 1989 (abans que la resta de sectors) i a partir d'aquest any presenta una evolució erràtica, però amb una possible tendència alcista a llarg termini.

Es constata, tanmateix, que el nombre d'hores respecte a la jornada real també ha tingut una tendència a disminuir, paral'lelament a la reducció de la jornada pactada, bàsicament per dos motius que es compensen entre ells: disminució progressiva de les hores extres i disminució de les hores perdudes.

Pel que fa a la reducció del nombre d'hores extraordinàries, aquesta no és excessivament gran, però s'emmarca en un context en què es pren cons- 


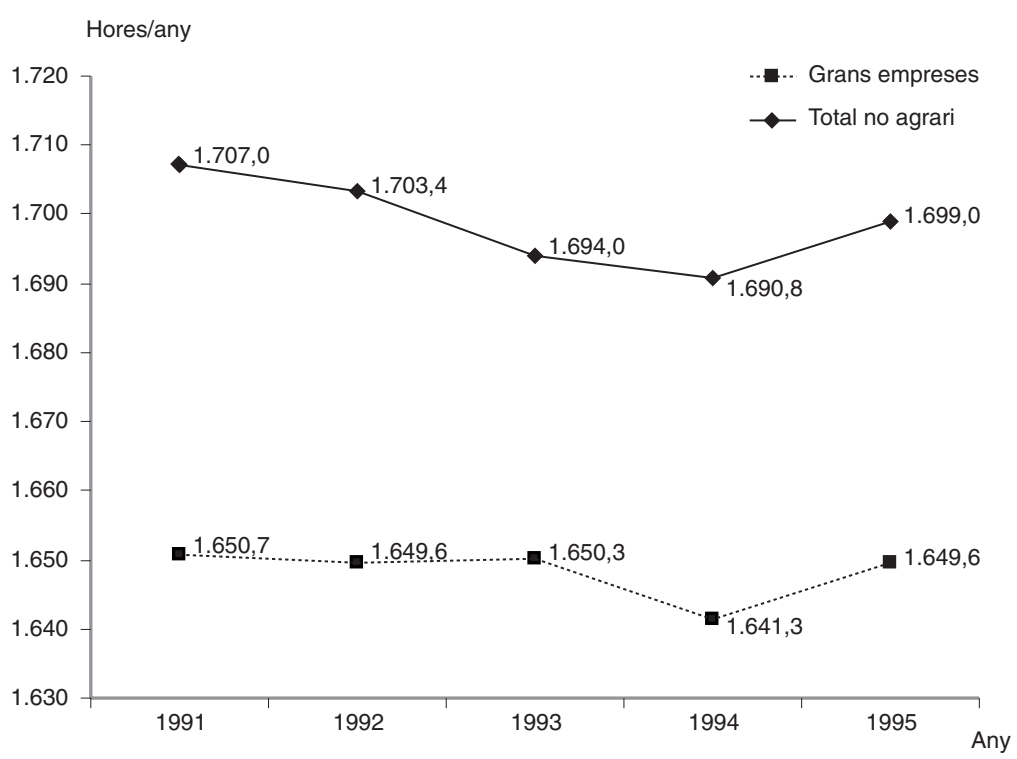

Figura 3. Comparació del nombre d'hores pactades en els convenis col·lectius, amb el sector grans empreses (1991-1995). Total convenis, sense el sector agrari.

ciència de la necessitat d'eliminar-les, i tota disminució en aquest aspecte és positiva.

I gualment, trobem una disminució en el nombre d'hores perdudes, tampoc gaire important però que pot tenir causes d'origen molt diferent. Podria deure's a increments en les mesures de seguretat i salut laboral, una preocupació més gran per temes relacionats amb la gestió de recursos humans (noves formes d'organització del treball que comporten més motivació del personal) 0 d'altres indubtablement positives, però creiem que es deu principalment a la proliferació de contractes precaris, fet que condiciona el comportament del treballador i porta que no es perdin hores de treball per a disposició pròpia, per permisos retribuïts o fins i tot per causes relacionades amb l'estat de salut, perquè són aspectes que juguen implícitament a l'hora que el contracte es renovi o no.

Cal destacar únicament el gran descens del'absentisme l'any 1993 (un any de crisi, cosa que es veu en l'increment de les hores perdudes per regulació d'ocupació), data des de la qual s'ha estabilitzat.

També es pot veure que en les grans empreses la jornada efectiva és inferior al total de les empreses ${ }^{14}$, amb una diferència que es manté més o menys constant. 


\section{Distribució de la jornada}

M olts convenis fan ús de la possibilitat de disposar del límit de quaranta hores setmanals i/o nou hores diàries de treball, ja sigui de forma explícita o en regular l'horari de treball (la qual cosa possibilita la distribució irregular de la jornada, normalment per causes organitzatives i productives), a fi i efecte d'afavorir la competitivitat de les empreses afectades pel conveni. Així, algunes mesures que actuen en el sentit d'incrementar la irregularitat són:

- Possibilitat d'adaptar el calendari laboral a les noves circumstàncies.

- Distribució irregular de la jornada setmanal.

- Regulació de la disponibilitat del treballador al servei de l'empresa. Aquesta fixació d'un temps de disponibilitat permet a l'empresa obtenir més temps de subordinació sense pagar al treballador més que allò que realment treballa. N ormalment es compensa amb un salari superior al que es pactaria sense aquesta disponibilitat.

La setmana laboral s'estipula habitualment de dilluns a divendres, però, tanmateix i segons l'activitat o el sector, s'inclou la jornada de dilluns a diumenge. En alguns convenis es compensa amb descansos el fet de treballar en dia festiu.

És habitual en els convenis d'empresa que es produeixi I'establiment de diferents horaris en cada centre de treball, a fi que sigui possible adaptar-se més bé a les necessitats de l'empresa.

La jornada de treball també s'irregularitza de vegades en benefici del treballador. Alguns exemples d'això poden ser:

- Alguns convenis disposen de certes hores per a assumptes propis dels tre balladors, així com d'una flexibilització quant a l'horari d'entrada i de sortida (horari flexible).

- La reducció del'horari en l'època estiuenca, així com la conversió de l'horari en intensiu.

Els horaris normalment són fixats per l'empresari o pactats en convenis collectius.

Q uan es pacta una jornada irregular, normalment aquesta és distribuïda per l'empresari, mentre que en pocs convenis es preveuen mecanismes formalitzats de diàleg. La distribució irregular normal ment ha de ser restringida a la concurrència de certes causes (tot i que normalment la definició d'aquestes és suficientment àmplia per a donar tot tipus de facilitats a l'empresari). Els repre sentants dels treballadors normalment només tenen dret a ser informats $i$, en pocs casos, a participar en les decisions.

Alguns convenis estableixen un nombre màxim d'hores que es poden distribuir irregularment, i totes les que n'excedeixin s'han de considerar com a hores extraordinàries. 
La irregularització de jornada exigeix en determinats convenis un preavís al treballador afectat. En alguns casos es compensa econòmicament 0 amb descansos addicionals (de vegades es regula la forma concreta de compensació).

Sovint s'exceptua de la irregularització de la jornada determinats col·lectius de treballadors, com els nocturns o els treballadors a torns.

H ores extraordinàries 15

Les hores extraordinàries gaudeixen normalment d'una regulació expressa en els convenis col·lectius.

En aquests convenis trobem que:

- Normalment es defineixen les hores extraordinàries de forma similar a I'Estatut dels Treballadors.

- Comença a ser habitual que consti un compromís de reducció del nombre d'hores extraordinàries realitzades, per tal de crear ocupació. Am aquesta finalitat normalment se suprimeixen o es redueixen les hores extraordinàries «habituals»16, es real itzaran les de força major i només es mantindran les hores extraordinàries estructurals ${ }^{17}$ si no és possible utilitzar una nova contractació per a cobrir les necessitats de l'empresa.

- En bastants convenis s'estableix, tot i pregonar la seva voluntat de reducció, el màxim de vuitanta hores anuals, tal i com especifica la llei, però d'altres en determinen d'inferiors. En algun cas, es concreta el nombre d'hores que cal realitzar per períodes més curts, fet que es pot deure al pes dels sindicats en els àmbits de negociació concrets.

15. Les hores extraordinàries sorgeixen quan apareixen causes que exigeixen una perllongació de la jornada de treball. L'article 35.1 ET entén com a hores extraordinàries aquelles que es realitzin sobre la durada màxima de jornada ordinària de treball fixada en l'article 34 ET. $\mathrm{H}$ auran de ser considerades hores extraordinàries:

- Totes aquelles que superin la jornada anual de treball (o la corresponent a cicles temporals inferiors).

- Totes aquelles que superin la durada setmanal de la jornada ordinària.

Les hores extraordinàries, segons l'article $35.4 \mathrm{ET}$, tenen caràcter no causal i són voluntàries, excepte si shan pactat en conveni col.lectiu 0 contracte de treball, tot i que es pot pactar també una negativa justificada. D e totes formes, és sabut per tots que la voluntarietat sovint no es dóna en la pràctica, sobretot en aquells treballadors amb contracte temporal, ja que la seva negativa esdevé en moltes ocasions una causa no explícita de la no renovació del contracte.

16. Són aquelles a les quals es recorre, més que per a atendre necessitats anormals de l'empresa, per a eludir la contractació de nous treballadors. La tendència dels pactes socials era la seva desaparició amb el propòsit de fomentar la contractació i contribuir a la lluita contra l'atur.

17. Les hores extraordinàries estructurals són les degudes a exigències del procés productiu, com ara comandes inesperades, períodes punta de producció, absències imprevistes, canvis de torn, etc. Els sindicats han admès aquesta modal itat sempre i quan les necessitats no es poguessin atendre a través de contractes temporals o a temps parcial. 
- La tendència general és deixar que les hores extraodinàries siguin voluntàries, excepte en els casos de força major. Q uan s'estableix l'obligatorietat en supòsits diferents a aquest es fa de forma matisada i justificada.

- Les hores extraordinàries es poden retribuir econòmicament o compensar mitjançant descans. És més habitual el cas darrer. Això està lligat a la voluntat de proporcionar més flexibilitat a l'empresa, que pot usar les hores extraordinàries com a instrument per a la irregularització de la jornada si les compensa en els terminis marcats (normalment quatre mesos), perquè no computaran com a tals. D e vegades es preserva la flexibilitat prohibint la compensació quan es donin puntes de producció. En alguns casos s'estableix un percentatge màxim retribuïble i la resta s'ha de compensar amb descansos.

- En els convenis que permeten escollir entre els dos sistemes, normalment qui tria és l'empresari, tot i que en alguns convenis es dóna la possibilitat d'elecció al treballador o hi ha una remissió a l'acord individual entre empre sari i treballador.

- S'estableix un recàrrec habitual del 75\% respecte al pagament de les hores ordinàries 18 , en consonància amb allò que regulava l'antiga legislació, però en d'altres s'estipulen recàrrecs superiors o inferiors, fins a igualar en molts casos les hores extres a les normals, de manera que aquelles assoleixen el mínim assenyalat en l'actual legislació (art. 35.1 ET).

- Sembla que hi ha una tendència envers el fet que si les hores extres es realitzen en dies festius o bé en horari nocturn, estan més recompensades.

- Sovint la forma de control de les hores extraordinàries reprodueix allò que diu l'Estatut dels Treballadors i només en al guns convenis saborda la problemàtica de la consideració de les hores extraordinàries en el cas de jornades irregulars. La negociació col·lectiva també acostuma a establir la freqüència amb què cal informar els representants dels treballadors, el contingut de la informació (normalment el nombre d'hores, causes, distribució per seccions, etc.) i a quina representació (unitària i/o sindical) cal donar la informació.

18. Segons l'article 35.1 ET, cal una retribució, que es pactarà per conveni o contracte, que no sigui inferior a la de l'hora ordinària (en un compromís per a defensar l'ocupació, ja que, si no fos així, els empresaris hi recorrerien sistemàticament; a més, amb això es recull la interpretació jurisprudencial al respecte) o la seva compensació amb descansos.

Amb la supressió del límit mínim de remuneració (el recàrrec establert en l'ET '80) es pretén desincentivar la realització d'hores extraordinàries per part del treballador. N o obstant això, aquesta mesura té una contradicció en la pràctica, ja que, tal com s'ha comentat, la voluntarietat de les hores extraordinàries és, en moltes ocasions, només en teoria i allò que es dóna en realitat és l'obligació de realitzar una sèrie d'hores, per les quals es percep a canvi una compensació més baixa. Per tant, amb aquesta reducció del límit mínim allò que s'està donant no és tant una desincentivació de cara al treballador com una incentivació de cara a l'empresari. 


\section{Com procedir a una reducció de la jornada?}

Les opcions per a reduir progressivament la jornada de treball poden ser tres:

- N egociació directa de la reducció de la jornada amb o sense reducció proporcional del salari i amb o sense un període de convergència, idoni per a empreses o sectors sense variacions substancials en els cicles productius.

- D esenvolupament del contracte a temps parcial anualitzat, que podria seguir les directrius del recent Real Decret-Ilei 15/98 de mesures urgents per a la millora del mercat de treball en relació amb el treball a temps parcial i el foment de la seva estabilització (BOE de 28 de novembre de 1998).

- Potenciació de la noció d'optimització de la jornada a través d'un joc més gran i millor de la distribució irregular de la jornada.

Les dues darreres opcions serien òptimes per a aquelles empreses 0 sectors amb cicles productius variables.

Pel que fa als diferents procediments que es poden adoptar per arribar a una reducció de la jornada laboral, analitzarem les formes més usuals: acord marc, conveni col-lectiu i llei. C ap mesura no és la ideal perquè cada una pot tenir els seus avantatges $i$ els seus inconvenients, això depèn del context històric, econòmic, social i polític del moment.

Els factors que s'analitzaran són:

- La rigi desa de la mesura, ja que aquesta afecta clarament la possibilitat d'adaptació de les empreses a aquesta.

- La uniformitat que aconseguiria, ja que aquest factor influeix sobrela generalització o no de la millora.

- L'efectivitat de la mesura, sobretot quant a la creació d'ocupació.

- El grau de desigualtat en les condicions d'ajust entre les diferents tipologies d'empresa.

Llé 19

Segurament, la decisió més rígida seria la imposició d'una reducció de la jornada mitjançant una llei. Aquesta mesura, pel fet de ser d'obligat compliment,

19. D estaquem per la seva posible influència les principals disposicions que el projecte de llei M artine Aubry preveu:

- La reducció de la durada legal dels treballadors (exceptuant els funcionaris i els de certes empreses públiques com RAT P, SN CF, etc.) a trenta-cin hores setmanals el primer de gener del 2000 per a les empreses de més de vint treballadors, i el primer de gener del 2002 per a les altres.

- Una novallei a l'any 1999 per fixar les modalitats de lestrenta-cinc hores. Així i tot, l'art. núm. 2 de la Llei convida les organitzacions patronals i els sindicats a negociar d'aquí al 2000 les modalitats de la reducció efectiva del treball, que podran ser molt variades.

- Diverses ajudes econòmiques a les empreses que abans del 2000 redueixin la jornada laboral en trenta-cin hores setmanals o menys. Aquesta ajuda està condicionada a la contractació d'un determinat nombre de treballadors, tot preservant-ne els llocs de treball.

- Un sistema de control i de sancions per aconseguir l'acompliment de la llei. 
hauria de suposar una uniformitat entre els diferents àmbits $i$ sectors, i, alhora, hauria de resultar el procediment més efectiu; això no obstant, al llarg de la història no sempre ha estat així, recordem que les primeres lleis laborals van resultar totalment ineficaces a causa del seu incompliment i d'una manca de control. D arrerament, sembla que aquest sistema és molt més eficaç, i si observem el darrer precedent normatiu espanyol de l'any 83 veiem que efectivament s'aconsegueix una reducció important de la jornada. Adoptar aquest criteri pot suposar una uniformitat entre els diferents àmbits i sectors, però alhora també pot arribar a ser font de desigualtat entre les diferents empreses, ja que podria no contemplar les diferències existents entre empreses grans $i$ petites, les que es dediquen a una activitat o a una altra, etc. Justament, aquesta mesura legislativa, en principi igual per a tothom, ha estat un dels temes de més polèmica a França.

També hem de tenir presents altres conseqüències a I'hora d'analitzar els avantatges i els inconvenients d'una regulació de la jornada mitjançant una llei:

- El resultat d'adoptar aquest procediment podria tenir diferents efectes segons els terminis que es fixin des de la data de promulgació de la llei fins a la seva entrada en vigor: si són massa curts, no permetrà un ajust suficientment adequat de les empreses i de les seves estructures productives a la reducció de jornada. Per contra, si el termini és molt més ampli i preveu les possibles diferències entre les empreses (tal com preveu la llei francesa), permetrà més ajust i adaptació.

- Si la llei no preveu que paral-lelament a la reducció de la jornada hi hagi un manteniment del salari, els treballadors amb rendes més baixes serien els que es veurien més perjudicats. Per evitar això, la llei hauria de preveure uns trams, en els quals la reducció del salari fos nul.la o menor ${ }^{20}$.

- A França i a Itàlia es preveuen subvencions econòmiques que sempre impliquen despeses que han de sortir del Fons de Pressupostos de l'Estat. Això, en un context on sintenta reduir al mínim el dèficit públic, probablement provocaria una reducció dels diners destinats a unes altres partides, i el més segur és que serien aquelles que tinguessin una mínima repercussió sobre l'opinió pública.

\section{Conveni collectiu}

Arribar a un acord de reducció de jornada per conveni collectiu, comparat amb la llei, és un procés d'aplicació més lent, en el sentit que si analitzem per exemple el que s'ha pactat, quant al còmput de la jornada, en un període de dos o tres anys, observem que les variacions són poc significatives. Alhora, però, podríem considerar-ho com una mesura més progressiva perquè permet establir un pla de reducció de jornada, a mitjà i llarg termini, en els convenis

20. Aquesta injerència en el contingut de la negociació es pot efectuar en virtut dels articles 40.1 i 131 de la Constitució espanyola (amb l'objectiu de fer millor política de rendes, com seria el cas), però seria necessària la consulta als grups afectats. 
de vigència superior a l'any; això no obstant, segons els convenis que hem examinat, les reduccions de jornades previstes són mínimes o quasi nul·les i generalment la seva regulació poc minuciosa minimitza el seu impacte real. Fins i tot en alguns sectors s'observa una tendència a augmentar lleument la jornada màxima. Talment, suposa un criteri molt més flexible perquè permet que els salaris i/o el temps de treball s'adaptin a l'evolució de la productivitat a curt termini (sobretot en els convenis que es pacten anualment). Així mateix, permet que els actors socials canviïn les seves estratègies de negociació, en funció de l'evolució de l'empresa o sector. Les necessitats de cada sector o empresa es tenen més en compte, però en contrapartida pot originar grans desigualtats, especialment a nivell empresarial, d'acord amb la força d'implantació i de negociació dels diferents sindicats.

\section{Acord marc}

Un acord marc 21 probablement seria la millor solució, perquè hi trobaríem el consens de tots els actors socials, i a la vegada s'aconseguiria més uniformitat entre els diferents sectors, de manera anàloga a la llei. M alauradament, arribar a aquest tipus de pactes és un procés de gran dificultat a causa, segurament, de la falta de voluntat dels actors socials, de la manca de tradició negociadora i de les dificultats d'aplicació vinculant als àmbits inferiors.

Aquí, a Espanya, per la dèbil posició negociadora dels sindicats (baixa afiliació, poca tradició, globalització econòmica22... ), els acords han estat i són poc efectius, tot i que, com a mesura transitòria de reforç a la regulació a través de conveni col·lectiu, podria desenvolupar un important paper pedagògic i estructurador.

En conclusió, el fet d'aconseguir una reducció de la jornada mitjançant un acord marc és difícil d'assolir per la complexitat ja esmentada. A través de conveni col'lectiu tampoc seria factible a mitjà termini, a causa de la lentitud observada i a la seva possible reversibilitat, ja que es podria donar un efecte contraproduent i les jornades en comptes de disminuir podrien augmentar. Per aquestes raons, creiem que la via més factible en aquests moments per aconseguir una reducció de la jornada laboral de caire general, seria la seva legislació a través d'una llei, que es combinés amb la negociació col·lectiva.

\section{Postures dels agents socials}

La reducció de la jornada laboral a trenta-cinc hores setmanals és, ara per ara, un dels temes més debatuts, especialment entre forces polítiques, sindicats i àmbits empresarials, que compten amb opinions ben diferents.

21. Un acord marc té la mateixa eficàcia erga omnes i eficàcia jurídica normativa que els convenis estatutaris de cara a les unitats de negociació inferiors si acompleix els requisits establerts per als convenis col lectius per l'Estatut dels Treballadors.

22. Sobre aquest particular, vegi's R ECIO, Albert. «Sindicatos, globalización económica y crisis ambiental», en aquest mateix número de PAPERS. 


\section{Els sindicats}

Les forces sindicals convençudes que aquesta mesura és essencial per crear ocupació, busquen arribar a un consens social. D 'aquesta manera, el lema «- hores + treball, trenta-cinc hores per crear ocupació» encapçala la crida de les seves mobilitzacions per tal de convèncer la societat. I és que sense el convenciment del'opinió pública difícilment arrelaran els dificultosos acords amb la patronal o el Govern. Reivindiquen una llei de màxima jornada laboral setmanal de trenta-cinc hores per qüestions de solidaritat i uniformitat, ja que aquesta via seria l'única manera que la reducció afectés tots els treballadors, des dels més forts fins als més dèbils.

UGT i CCO 0 , en un primer moment, demanaven una complementarietat d'instruments legals i convencionals, exigien al Govern una llei de disminució de la jornada fins a trenta-cinc hores, amb horitzó vers el 2000, i que la negociació col-lectiva fos al hora el vehicle per al repartiment de la feina dins de les empreses. En aquests moments, però, són conscients que pactar reduccions de jornada a través dels convenis col lectius trobarà l'oposició de la Patronal i, en relació amb les hores extraordinàries, una resposta política adversa per part dels treballadors.

D 'altra banda, podria ser que en sectors on el moviment sindical és més fort, potser sí que es podria aconseguir una reducció important de la jornada, però la resta que no té força sindical, com ho faria?

A més, contra l'opinió de la patronal d'arribar a un acord per conveni colllectiu, i per tal de reforçar el seu argument, al-leguen que en els darrers cinc anys els convenis han augmentat la jornada laboral en una mitjana de tretze hores, ja que han passat de 1.763 hores anuals l'any 1993 a 1.776 hores el 1997.

Un detall que es pot observar en aquesta reivindicació és que la finalitat, fins ara sempre perseguida, que buscava millores en les condicions laborals $i$ en la qualitat de vida dels treballadors, ha passat a esdevenir una estratègia per crear ocupació. Així, el secretari general de C CO O del Vallès O ccidental, Juan Guil, considera que la reducció de jornada no és una mesura més per crear ocupació, sinó que és la mesura central, i al·lega l'argumentació següent:

la població ocupada és més o menys la mateixa que el 1977, i, en canvi, el PIB, la riquesa del país, s'ha doblat i la productivitat de les empreses s'ha multiplicat per tres. I com que en períodes de creixement econòmic l'ocupació que es crea és inferior a la que es destrueix en períodes de crisi, condiciona que l'atur estructural sigui cada vegada més el evat. Per tant, considerem que la reducció de la jornada sense reducció salarial és essencial per combatre l'atur, però que evidentment ha d'anar acompanyada d'altres mesures, com acabar amb les hores extres, crear noves feines, més inversió pública i jubilacions anticipades $^{23}$.

23. GuIL, Juan. «Reducción de la jornada laboral». D iari de Sabadell, 22 d'abril de 1998, p.10. En un sentit similar FerRer SAIS, Antonio. «Empleo y solidaridad: trabajar por las 35 horas». El País, 30 de març de 1998, p. 68. 
Aquesta última alternativa, però, seria qüestionable tenint en compte que el nostre sistema deficitari de seguretat social suporta ja, amb dificultats, el pes cada vegada més gran de prestacions per jubilació. En canvi, que considerin que paral lelament a la reducció de la jornada ha d'acompanyar-se l'eliminació de les hores extres, creiem que esdevé una mesura fonamental, ja que, si no, es cauria en el parany que aquesta reducció de la jornada es podria veure compensada per la realització d'hores extraordinàries $i$, en conseqüència, no saconseguiria la finalitat perseguida d'incrementar l'ocupació, ja que els empresaris sempre optarien per la mesura que els resultés més flexible i econòmica. Però, com controlar la realització d'aquestes hores si moltes no són declarades com a tals? I és que el mateix límit de vuitanta hores imposat per la llei, condiciona que molts empresaris decideixin camuflar aquestes hores i abonar-les sota conceptes com ara primes, dietes i desplaçaments, etc. Però no són els únics implicats, ja que els mateixos treballadors accepten la realització d'aquestes hores, uns per pressió (col-lectius amb contractes precaris que tenen anul-lada la seva capacitat de decisió), i d'altres per pròpia voluntat a fi de satisfer necessitats econòmiques de segon ordre. M oltes vegades són els mateixos representants dels treballadors els que pacten la realització d'aquestes hores i a la vegada pacten la forma com es pagaran, per tal de no declarar-les i poderne realitzar com més millor. I aleshores és quan sorgeix la dificultat, qui ha de denunciar que s'estan realitzant hores extres, els aturats?

Per tal de fomentar la contractació, el secretari general de la UGT de C atalunya, J osep M aria Álvarez, considera que la G eneralitat hauria d'aprovar incentius econòmics per a les empreses que creïn ocupació a través de la reducció de la setmana laboral24. D 'aquesta manera s'amortiria el possible augment del cost laboral unitari causat per la contractació de nous treballadors 25 .

Es vol aconseguir aquesta reducció de la jornada sense reducció salarial perquè es considera que amb l'actual moderació salarial ja s'està sacrificant poder adquisitiu i perque els salaris són molt més baixos que a la resta d'Europa. Però també creiem que existeix una altra raó fonamental, i és que una reducció de jornada que comporti una reducció salarial no seria acceptada pels actuals treballadors, que són en definitiva els veritables pilars de les cúpules sindicals. Així, en un primer moment no es pacta una reducció, però a la llarga qui ens assegura que no es traduirà en una congelació salarial?

\section{La Patronal}

L'opinió de la Patronal durant el transcurs d'aquests darrers mesos, se centra en la negativa de la reducció de la jornada a trenta-cinc hores, i de negociar amb els sindicats:

25. D e fet, aquesta proposta ja ha estat contemplada al $D$ ecret del $D$ epartament de Treball de la G eneralitat de Catal unya 248/1998 de 22 de setembre. 
- La primera al.legació dels empresaris es refereix als resultats econòmics. Segons el president de la CEOE26, s'ha de mantenir l'actual política econòmica perquè està donant bons resultats sobre la capacitat competitiva de les empreses i la creació d'ocupació.

Sota aquesta concepció, pensem que no té cabuda la reducció de la jornada de treball. El problema que podria plantejar aquesta premissa es basa en el fet que la creació d'ocupació no va aparellada al ritme de creixement que s'està donant en l'economia espanyola, opinió compartida amb els sindicats, i, per tant, shaurien de matisar aquests bons resultats, i més si tenim en compte el tipus d'ocupació precària que s'està creant. Considerem que shauria de donar una obertura a la política econòmica per incloure possibles alternatives.

- El segon motiu de desacord es refereix als efectes sobre la competitivitat27, ja que és un dels factors clau en el món empresarial. Esdevé una de les qüestions més reclamades $i$ exigides pels empresaris dels diferents països. Referent a això, la patronal afirma:

Q ue la competitivitat s'ha d'aconseguir a partir d'una convergència més gran en costos salarials, perquè amb l'entrada de l'euro no es podrà devaluar. S'ha aconseguit convergencia en preus, però, encara, els costos laborals augmenten aproximadament el doble que a la U nió Europea (1\% versus 1'9\%) ${ }^{28}$.

Efectivament, amb l'entrada de l'euro la nostra economia en els moments de crisi no tindrà la capacitat per a devaluar, però hem de tenir present tanmateix que aquest fet afectarà la resta de les economies europees $i$, per tant, no hauria d'esdevenir una condició negativa únicament per a nosaltres. EI problema, però, és que es donen moltes diferències entre els països i només

26. El País, 25 de març de 1998.

27. Atès que per a les empreses espanyoles probablement la reducció de la jornada sense reducció de salaris constituiria un increment significatiu en els costos, cal preguntar-se quins altres avantatges poden tenir aquestes empreses si segueixen desenvolupant la seva activitat en el nostre país, cosa que és imprescindible per tal que els llocs de treball que es creïn a curt termini es mantinguin a més llarg termini.

M ichael Porter (1990), en una anàlisi sobre avantatges competitius nacionals va trobar que: a) L'entorn nacional del'empresa exerceix una poderosa influència sobre el seu desenvolupament. b) El manteniment d'un avantatge competitiu a escala internacional depèn dels aspectes dinàmics de l'avantatge competitiu, és a dir, de la innovació i la millora constants.

Així, Porter formulà el seu model del diamant nacional, segons el qual l'avantatge competitiu depèn de quatre característiques: condicions dels factors, sectors connexos i auxiliars, condicions de la demanda i estratègia, estructura i rivalitat.

Per tant, vegi's que per a compensar l'increment de costos que pot suposar la reducció de la jornada cal efectivament actuar sobre la mà d'obra, però també hi ha camp d'actuació en temes referents a altres aspectes. Cal plantejar-se la mesura de reducció de jornada com quel com més global que simplement una actuació sobre la mà d'obra (és a dir, només polítiques actives d'ocupació), tot i que aquesta actuació és indispensable.

28. El País, 30 de març de 1998. 
es troben amb la necessitat de devaluar els més perjudicats, l'Estat espanyol es troba en aquesta situació.

N o obstant això, també cal tenir en compte que els costos laborals espanyols estan per sota de la mitjana de la Unió Europea, cosa que fa que sigui fins a cert punt normal que sintenti convergir en nivell de salaris amb laUE.

Aquest fet mostra que les empreses espanyoles exportadores o les que fabriquen productes susceptibles d'ésser importats estan competint bàsicament a través del preu, quan aquest és un avantatge competitiu que serosiona amb relativa facilitat (a més del fet que Espanya fa temps que no és un país líder en costos a causa de la irrupció en l'escena internacional dels nous països industrials com els del sud-est asiàtic, el M agrib, etc.) ${ }^{29}$.

Pel que fa referència a les cotitzacions, tenen com a contrapartida el sufragi de l'estat del benestar però, per altra part, amb una reducció de la jornada, els costos laborals no descendirien sinó que probablement augmentarien i, per tant, els efectes anirien en direcció contrària a la desitjada30.

Es parteix, per tant, del fet que per augmentar la competitivitat és necessari anar reduint les cotitzacions, sense plantejar els efectes que pot tenir aquest fet vers l'estat del benestar, 0 , en tot cas, es considera que amb aquest tipus d'iniciatives s'aconseguiria incrementar l'ocupació i, per tant, es neutralitzarien els efectes negatius.

- Un tercer focus de desacord el trobem en les possibles formes d'incentivació. Foment del Treball s'oposa al fet que es preveguin una sèrie d'incentius públics per a les empreses que creïn ocupació a través de la disminució de la

29. La por de no ser competitius i d'estar en condicions inferiors amb l'entrada de l'euro, també és present a França, i segons l'opinió del president de l'associació francesa de bancs «la reducció de la jornada és un error econòmic greu», $i$ arriba fins $i$ tot a insinuar que «esdevé una incitació per les empreses de buscar unes economies per sobre d'aquesta aposta pel que fa al seu compte d'explotació».

Les dades referents als costos laborals reflecteixen certament un problema, però no hem d'oblidar que la política que s'està seguint en aquests moments és vers el consum, i curiosament les moderacions salarials xoquen amb aquesta concepció. LeFigaro, 1 de desembre de 1997.

30. Si novament ho comparem amb el nostre país veé, també s'exposa que la mà d'obra, per exemple, en el sector del vidre representa un $50 \%$ del cost de la producció i les càrregues socials davant una reducció de la jornada, augmentarien entre un 10 i un $13 \%$, la qual cosa, i segons els empresaris del sector, no afavoriria l'ocupació. Per tant, consideren que, «no se'ns podria replicar el fet de produir fora de França». A més, es considera que el fet de mantenir els sous provocaria que la remuneració augmentés en un $2,5 \%$ i que aquest cost suplementari provocaria una alça del conjunt dels salaris en un $12 \%$. Aquest augment, segons la patronal francesa, «tindrà unes conseqüències inflacionistes inconciliables per a passar a la moneda única. França serà una mica menys atractiva pels estrangers». Le Figaro, 1 de desembre de 1997.

Així, l'interès per part de la patronal de cara a permetre que les empreses puguin ser més competitives, gira a l'entorn de reclamar que les cotitzacions socials baixin 3 punts l'any 2000. El País, 25 de març de 1998. 
jornada o bé per disminuir les hores extres, ja que, per una part, recorda que existeixen ajudes estatals per a contractar a més grans de quaranta-cinc anys $i$ joves $i$ «els ajuts no poden cobrar-se dues vegades» i, per l'altra, el problema és saber quines hores són substituïbles i com es realitzarà el seu control administratiu31.

És rellevant la importància que es dóna a la possibilitat de rebre incentius i al fet que al guns d'aquests podrien doblar-se. La llei no és una cosa estàtica i constantment hi ha reformes, creacions d'altres decrets, Ileis, etc. M olts dels ajuts que sesmenten tenen una durada determinada i, a més, caldria assenyalar la seva escassa incidència pel que fa a la seva utilització. Per tant, la preocupació de la patronal respecte a aquest problema no és més que una manera d'eludir aquesta possible reducció.

Pel que respecta a les hores extraordinàries, efectivament seria necessari una legislació que determinés tots els aspectes possibles, així com el seu control. Aquest darrer punt esdevé un problema, ja que tant empresaris com treballadors, cadascun en pro dels seus interessos, són contraris a aquest control.

- Un punt on el desacord és molt alt és en la qüestió de la seva obligatorie tat. La patronal de petites i mitjanes empreses Safes-Pimec es desmarcarà de la posició de Foment del Treball, que sí que ho acceptaria sempre que sigui «voluntària per a les empreses» i si «la lletra petita del pacte manté un esperit obert»32.

Bàsicament la negativa se centra en en el fet que es realitzi una regulació per llei, ja que això comportaria que, obligatòriament, totes les empreses haurien d'atenir-se a la reducció. Això és el mateix que succeeix a França, on la patronal és totalment contrària a la seva general ització «autoritària, obligatòria i datada per a totes les empreses»33. Amb la voluntarietat, que es real itzaria a través de negociació col·lectiva, el marge seria molt més ampli, tot i que pensem que aleshores la seva incidència seria escassa i amb possibles divergències segons la grandària de l'empresa34.

31. El País, 24 de març de 1998 i 1 d'abril de 1998.

32. El País, 24 de març de 1998.

33. LeFigaro, 22 de desembre de 1997.

34. Resulta significatiu el fet que en una enquesta realitzada a empresaris francesos en la qual se'ls demanava l'opinió vers l'avantprojecte de llei de reducció de la jornada a trenta-cinc hores, planteja moltes similituds amb l'opinió que té la patronal del nostre país. Així doncs, les dades de l'enquesta indicaren que:

- El 85\% dels caps d'empresa entrevistats s'oposaven i destacaven els efectes negatius.

- Un 66\% pensaven no fer servir els ajuts.

- D onen prioritat a la disminució de les càrregues socials per a lluitar contra l'atur.

- Un 93\% estima que no han estat escoltats.

- Un 93\% opina que hi ha altres polítiques que permetrien disminuir l'atur i no han estat assajades.

L'oposició a la reducció de la jornada i els seus efectes negatius esdevé un discurs que es repeteix en els diferents països i al llarg del temps. Tal com ja hem comentat, l'any 1933 
En definitiva, els arguments de la patronal giren a l'entorn de cercar més flexibilitat i menys costos, i xoquen amb una mesura que pot arribar a ser contrària a aquesta.

\section{Model economètric d'efectes de la reducció de la jornada a curt termini}

La reducció de la jornada, com s'ha vist, pot tenir múltiples efectes, a més de la seva influència sobre l'ocupació. Per tal de veure els efectes que es poden donar sobre l'atur, els preus, les importacions i les exportacions en absència de canvis en l'estructura productiva, l'organització de la producció i del treball, etc., procedim a formular un model economètric, que consta de set blocs diferenciats:

- O ferta de treball.

- Demanda de treball.

- Ingressos de la Seguretat Social per cotitzacions.

- Subsidis d'atur.

- Preus.

- Exportacions.

- Importacions.

\section{O ferta de treball}

L'oferta de treball depèn del volum de població, de la seva composició per edats i sexes i de la taxa d'activitat de cada grup d'edat i sexe.

La població i la seva distribució per edats i sexes s'estudia a partir d'unes projeccions demogràfiques confeccionades per I'IN E 35 .

Per a obtenir la taxa d'activitat es fa servir per a cada grup d'edat (16-19, 20-25, 26-54, 55-60, 60-65) i sexe el model següent:

$\left(\text { Taxa activitat }{ }_{\text {sexe edat }}\right)_{t}=a+b * t+c^{*}(\text { Taxa de creixement del PIB real })_{t}+$ $+d^{*}(\text { Taxa d'atur global })_{t-1}+e^{*}\left(T^{\prime} \text { axa d'atur } \text { sexe,edat }^{-} \text {Taxa d'atur global) }\right)_{t-1}$

la Sociedad para las Reformas Sociales féu tambéun recull d'opinions on els empresaris s'hi oposaven i destacaven els efectes negatius en el seu context.

A hores d'ara, aproximadament 1.148 convenis s'han acollit a la reducció de la jornada i, per tant, pensem que el percentatge que s'acollirà als ajuts probablement serà molt més ampli del que indical'enquesta. Si tenim en compte que es pot gaudir d'unes bonificacions a la Seguretat Social durant set anys (40\% el primer any i 30\% els sis anys següents) amb una contrapartida de dos anys de compromís per part de l'empresa, aquest tercer punt de l'enquesta resta inclòs, i es pot considerar com un guany de la patronal (Le Figaro, 8 de desembre de 1997).

35. Elaborades a partir del Cens de Població de 1991. 
Les variables explicatives del model són:

- El temps, per a veure si hi ha alguna tendència clara pel que fa a la taxa d'activitat d'algun grup.

- Taxa de creixement del PIB real, per tal de determinar l'efecte de substitució del treball reproductiu pel productiu i viceversa.

- Taxa d'atur global i del grup, per tal de veure el pes de l'efecte desànim.

Es pot observar que en els grups d'homes no hi ha cap tendència significativa o bé és negativa, mentre que en les dones, quan és significativa, la tendència és positiva. Això reflecteix el creixent accés de la dona al mercat laboral.

També cal observar que l'efecte del creixement del PIB sobre la taxa d'activitat femenina és molt més alt que sobre la masculina, cosa que mostra que la substitució de treball productiu per reproductiu és molt més acusada en les dones que en els homes.

Aplicant una taxa de creixement de l'economia del 3,7\%36, obtenim una població activa d'uns 16.900.000 persones per a 1998.

\section{D emanda de treball}

La funció de demanda de treball de l'economia depèn de la funció de producció d'aquesta economia. Per tant, depèn del valor afegit que genera l'economia (la producció) i els preus relatius dels factors productius (agrupables lògicament en capital i treball).

Per a aquest estudi s'ha utilitzat una funció de producció anomenada CES o d'elasticitat de substitució constant entre els factors productius ${ }^{37}$. Aquesta funció, tot i que no s'ha d'ajustar pas a la realitat millor que qualsevulla altra funció matemàtica, té característiques que la fan adequada com a representació simplificada del món real, com són:

- Productivitat marginal positiva dels factors, és a dir, cada unitat addicional d'un dels factors fa que augmenti la producció.

- Productivitat marginal decreixent respecte a l'increment de la quantitat emprada del factor, és a dir, cada unitat addicional d'un dels factors incrementa menys la producció que la precedent.

- La productivitat marginal d'un factor augmenta en incrementar-se la quantitat emprada de l'altre factor.

36. El País, 18 de març de 1998.

37. Aquest tipus de funcions de producció adopten la forma general de:

Producció $=g^{*}\left[K^{*} C^{-a}+(1-K) * T-a\right]-v / a$, on $g$ és indicatiu de l'eficiència de la tecnologia emprada, $\mathrm{K}$ indica el grau en què la tecnologia és capital-intensiva, $v$ representa els rendiments de la producció en augmentar el seu volum i a mesura la facilitat amb què el capital és substituït pel factor treball en estar relacionat amb l'elasticitat de substitució mitjançant l'expressió: Elasticitat $=1 /(1+a)$. 
Atès que a curt termini la quantitat de capital (inversions, en general) és bastant rígida, podem proposar una funció de demanda de treball 38 :

log hores emprades $=a+b * \log (V A B$ a c.f. $)+c * \log ($ Cost capital per hora $/$ / Cost mà d'obra per hora)

Per al 1998 es preveu una demanda d'hores de 21.635.387.850, és a dir, 13.537.093 persones. Per tant, com que la població activa seria de 16.900 .000 persones, l'atur se situaria en uns 3.363 .000 persones (aproximadament un $19,9 \%)$.

Ingressos de la Seguretat Social per cotitzacions

Com que les cotitzacions a la Seguretat Social són un percentatge del volum de salaris bruts, podem determinar-ne els ingressos per aquest concepte a partir de la determinació del percentatge que relaciona salaris bruts i cotitzacions $i$ el volum de salaris bruts obtingut en l'apartat anterior. Així, podem plantejar l'equació:

Cotitzacions a la Seguretat Social $=a *($ Sous i sal aris bruts $)=$ $=a^{*}$ (N ombre d'hores* Salari brut per hora)

Així, s'obté que el volum total de cotització seria d'uns 8.629.984 milions de pessetes, superior a la xifra actual i que permetria subvencionar les empreses per a una adaptació més bona al canvi.

\section{Reducció de despeses per atur}

Com que, lògicament, un increment en l'ocupació afectaria el volum d'atur, probablement també afectaria el volum de subsidis pagats per desocupació. Així, per al nivell contributiu plantegem la relació:

Subsidiats $=a+b *$ Temps $+c^{*}$ N ombre d'aturats + $+d^{*}($ N ombre d'aturats* Temps)

Per al 1998 la predicció és d'unes 700.400 persones, quan el 1997 fou aproximadament d'1.250.000. Això també suposa un excedent de fons que es pot destinar a subvencionar.

Per al nivell no contributiu la relació és:

Subsidiats $=a+b^{*}$ Temps $+c^{*} N$ ombre d'aturats + $+d^{*}$ (N ombre d'aturats* Temps) + e* Subsidiats contr.

38. Vegi's AA.DD . M odelo Econométrico de Política Laboral (1954-1971). M adrid: Secretaria Tècnica del M inisteri de Treball, 1969. 
Per al 1998 la predicció és d'unes 891.000 persones, superior a les aproximadament 700.000 del 1997. N o obstant això, l'efecte global sobre els subsidis per desocupació és d'alliberament de fons.

\section{Efectes sobre els preus}

Lògicament, també ens interessa saber quin és l'efecte de la reducció de la jornada sobre els preus, ja que aquests determinen fortament la competitivitat exterior a través del tipus de canvi efectiu real de l'economia. Així, plantegem la relació:

Increment de preus $=a+b *$ (Increment de salaris-Increment de la productivitat) $+c^{*}$ Increment dels preus de les importacions + $+d^{*}$ Increment de l'oferta monetària (ALP)

Si mantenim l'increment de preus de les importacions i l'increment del volum de diner en circulació com l'any 1997 i suposem que no hi ha increment de la productivitat (perquè no hi ha reorganització del temps de treball 39 ), podem predir una inflació propera al $9 \%$ (actualment és del $2 \%$ ).

Aquesta inflació seria més baixa com més elevat fos l'increment de la productivitat (ja que el diferencial existent entre l'increment dels salaris i l'increment de la productivitat es transmet aproximadament en un $60 \%$ ), però un increment de la productivitat faria que la demanda de feina fos menor, ja que faria canviar lògicament els paràmetres de la funció de producció de l'economia i, lògicament, faria variar els paràmetres de la funció de demanda de feina, que en deriva.

\section{Exportacions}

Atès que un increment en els sal aris no compensat per un increment en la productivitat provocarà un increment de preus, cal saber quina serà la incidència d'aquest sobre el volum d'exportacions, ja que aquest afecta sobre la producció i, lògicament, sobre l'ocupació. Plantegem la relació 40 :

Exportacions reals $=a+b^{*}$ Temps a UE $+c^{*}$ PIB real UE $+d^{*}$ (PIB real

UE*Temps aUE) + e*TCER UE +f* (TCER UE*TempsaUE)

En aquest model:

- El temps a la U E intenta veure la seva influència en el volum d'exportacions, perquè el canvi en els hàbits de consum dels països destinataris de les nostres exportacions és un procés que requereix un temps.

39. Ja que si hi ha una reorganització de la producció lògicament hi haurà un increment de la productivitat, que faria baixar la demanda de treball i també faria que la inflació no fos tan alta.

40. M odel basat en el d'Ana Yabar (El sector público en España: un análisis cuantitativo de política fiscal. M adrid: Instituto de Estudios Fiscales, 1977), reproduït a PuLID o, Antonio. M odelos econométricos. M adrid: Pirámide, 1989, p. 337-339. 
- EI PIB real de la UE intenta reflectir l'impacte en les nostres exportacions del creixement econòmic dels països destinataris d'aquestes.

- El tipus de canvi efectiu real envers la UE intenta reflectir la influència del preu sobre el volum d'exportacions, ja que TCER $=$ (T ipus de canvi nominal*Preus Espanya)/Preus UE. Així, tot increment en el TCER reflecteix els canvis dels preus de les nostres exportacions en termes de la moneda del país receptor de les exportacions.

Es veu que amb un increment dels preus del $9 \%$ i una inflació per a la UE d'un $2 \%$ (i un canvi nominal que suposem que no varia, com passarà en el futur escenari euro), les exportacions baixarien en aproximadament 1.850.000.000 pessetes reals de 1986 (uns 3.557.250.000 pessetes actuals) respecte a la situació sense la reducció de jornada conservant els salaris.

Això, com tot decrement de l'activitat interna, provoca, a mitjà termini, que la demanda d'ocupació sigui menor, ja que, com s'ha dit, la demanda de treball és una demanda derivada de les necessitats de producció.

\section{Importacions}

Lògicament, l'increment dels preus dels productes nacionals també ha de tenir repercussions sobre la demanda interior, que substituirà productes nacionals per productes importats, més barats. Així, s'estableix la relació41:

Importacions reals $=a+b * F B K F+c * R N B D+d *(R N B D *$ Temps a UE $)+$ $+\mathrm{e}^{*}$ TCER +f* (TCER*TempsaUE)

En aquest model:

- La formació bruta de capital fix intenta veure quin és l'efecte de la inversió sobre les importacions, ja que tradicionalment les èpoques d'alta inversió han provocat un increment de les importacions, perquè gran part de les inversions es cobreixen a través d'importacions.

- La Renda N acional Bruta D isponible intenta reflectir la relació entre la marxa de la nostra economia i la demanda de productes importats, ja que a més activitat i, lògicament, més capacitat de compra, el volum d'importacions será més gran.

- El Temps a la U E s'utilitza per a reflectir els canvis en els hàbits de consum, derivat de la permanència a la U nió Europea.

- EI TCER s'utilitza per a veure l'efecte de l'evolució dels preus dels productes nacionals sobre les importacions, per un efecte de desplaçament de la demanda cap a productes més barats.

41. M odel basat en el d'Ana Yabar (El sector público en España: un análisiscuantitativo de política fiscal. M adrid: Instituto de Estudios Fiscales, 1977), reproduït a PuLID O, Antonio. M odel os econométricos. M adrid: Pirámide, 1989, p. 337-339. 
La predicció per al 1998 és d'unesimportacions superiors en 186.000.000.000 pessetes reals de 1986 (357.650.000.000 pessetes nominals).

Els efectes serien fins i tot una mica més grans, ja que probablement hi hauria un sector important d'empreses que tendirien a invertir en capital per a automatitzar processos (per a reduir costos, substituint mà d'obra per capital) i, per tant, les importacions s'incrementarien com a conseqüència de l'increment de la formació bruta de capital fix.

Per tant, les conclusions que es poden extreure d'aquest model són:

- El descens del nombre d'aturats no seria gaire gran.

- La Seguretat Social obtindria recursos suficients (tant per un increment dels ingressos com per una disminució de les despeses) per a alleujar, almenys temporalment, el xoc que suposaria per a les empreses la reducció de la jornada. Aquesta reducció podria donar-se per un descens de les cotitzacions per a reduir els costos laborals 0 amb subvencions, la qual cosa potser seria preferible, ja que si es condicionessin aquestes subvencions a la creació d'ocupació aniríem més en la línia d'allò que pretén principalment la reducció de la jornada.

- Probablement es produiria un increment notable en les taxes d'inflació, fet derivat de la transmissió als preus de l'increment de costos laborals no compensat per un increment de la productivitat.

- Aquest increment en la inflació tindria un impacte negatiu sobre el saldo de la balança per compte corrent, és a dir, un deteriorament de la posició de I'economia espanyola respecte a l'exterior. Lògicament, això també afectaria el nivell d'activitat de l'economia de forma negativa.

Cal veure que aquestes previsions suposen que l'increment de productivitat serà nul (cosa bastant improbable) i que el salari es mantindrà (per tant, que pujarà el salari per hora). Aquests efectes negatius seran menors com més elevat sigui l'increment de la productivitat. N o obstant això, aquest també farà que la demanda de mà d'obra sigui menor.

Una altra solució seria no mantenir els salaris sinó que es rebaixessin una mica (per tal quel'increment del cost laboral per hora fos menor). Aquest fet podria provocar, això no obstant, més rebuig envers la mesura i, a més, canvis en les pautes de consum i estalvi.

\section{Conclusions}

A partir de les dades extretes de l'estudi del model, observem els riscos que pot comportar la reducció de la jornada pel que fa a la creació d'ocupació, ja que els efectes poden ser contraris als esperats. U na dada rellevant que ho corrobora, es troba en el fet que en els darrers vint anys s'han donat constants reduccions de la jornada i, per contra, l'atur ha augmentat.

Addicionalment, poden existir una sèrie de riscos, en el cas que no es realitzessin canvis, a més dels que directament deriven del model: 
- Si es manté el salari, probablement es passarà per uns quants períodes de congelació salarial, cosa que faria que l'economia tornés a una posició semblant a la inicial però que les rendes reals dels treballadors es veiessin reduïdes. Altrament, si es vol mantenir el salari real, s'entraria en una espiral d'inflació i increment de salaris que portaria al fet que la inflació anés encara més enllà de la xifra prevista 0 , més lògicament, a una política més restrictiva des del punt de vista fiscal (ja que la política monetària serà a les mans del Banc C entral Europeu), amb el consegüent descens de l'activitat i, lògicament, menys demanda de treball.

- H i ha la possibilitat que, a la llarga, les empreses intensifiquin la deslocalització de la seva producció a paîsos del nostre entorn amb un cost laboral inferior, un fet lògic en un context de globalització econòmica.

- Pèrdua d'atractiu que patiria Espanya com a receptora d'inversió productiva exterior, cosa que podria plantejar problemes per a la balança de pagaments.

- Pèrdua de competitivitat, que podria provocar que els empresaris optessin per deixar erosionar els seus marges de benefici (cosa bastant lògica en uns mercats en què l'oferta és més gran que la demanda i, per tant, és aquesta la que marca la majoria de les condicions) i, així, veure disminuir els seus incentius a la inversió i, consegüentment, a la creació d'ocupació.

- Les empreses més grans podrien pressionar les seves indústries auxiliars a reduir els seus preus per a poder compensar així el sincrements dels costos laborals suportats, la qual cosa donaria lloc a més dualització del mercat laboral, ja que en aquestes indústries auxiliars hi hauria més pressió en la negociació col lectiva per a reduir els costos laborals (per a poder-se mantenir en el mercat amb un mínim de beneficis). 0 , fins i tot, també podria generar un increment de l'economia submergida, que trobaria menys problemes per a precaritzar les condicions laborals.

- Les empreses podrien procedir a la reducció de la qualitat dels seus productes a fi de reduir els costos i poder mantenir els preus, cosa que tindria una influència negativa a la llarga, en un context en què la demanda cada cop exigeix uns nivells de qualitat més el evats.

- La possible mecanització de processos que es duria a terme, per a intentar reduir els costos laborals i minimitzar l'impacte negatiu sobre aquests que tindria una mesura com la reducció de jornada amb manteniment del salari, provocaria que les empreses espanyoles fossin més rígides quant a la seva forma de producció i quant a la possibilitat d'adaptar amb rapidesa la capacitat a la demanda, cosa que en els moments de descens de l'activitat seria clarament negativa.

- Existeix la possibilitat que l'increment de costos no compensables en certes empreses fos tan gran que poguessin acollir-se a les clàusules de despenjament salarial contemplades en els convenis, amb la qual cosa la regulació per llei que pretengués mantenir els salaris perdria efectivitat i es produiria més dualització del mercat laboral entre els empleats de les grans empreses i els de les petites empreses, ja que normalment aquestes 
treballen amb uns marges més baixos i seria més fàcil que hi haguessin de recórrer.

Cal tenir en compte que no seria possible defensar-se dels efectes derivats de la pèrdua de competitivitat exterior a través de devaluacions de la moneda (ja que amb l'euro no hi ha moneda nacional, sinó que la política monetària es troba en mans del Banc C entral Europeu; a més, en principi, no es poden fer devaluacions competitives sistemàticament), ni tampoc a través de la imposició de noves barreres comercials (perquè tant els aranzels com les barreres no aranzelàries no poden ser augmentades pel compromís que suposen tant la pertinença a la U nió Europea, pel que fa als països que en formen part, com a l'O rganització $M$ undial de Comerç, pel que fa a la resta de països). A més, tampoc és possible entrar a subvencionar els productes que es venen a l'exterior, ja que això aniria contra la política de competència de la U nió Europea (a més de provocar, si aquestes subvencions fan que el dèficit públic augmenti molt, sancions del Banc C entral Europeu en forma d'increment de les taxes d'interès i altres mesures monetàries de sanció, que frenarien encara més l'e conomia).

Per tant, cal fer quelcom per tal de modificar aquesta situació mancada de perspectives favorables, per tal de ser més competitius i poder compensar l'increment de costos i preus amb altres factors de competitivitat.

Per què la dinàmica de l'atur no continuï i per tal que les dades reflectides en el model no es compleixin, cal en principi aconseguir que l'elasticitat de la demanda respecte al preu és redueixi, és a dir, que la demanda del producte no depengui tant del preu. Un canvi com aquest suposa una modificació molt important pel que fa a la cultura i a les estratègies empresarials que s'han d'adoptar. Per tant, exposem, a manera de guia, quins serien, segons el nostre parer, els punts que caldria tenir presents:

- Passar d'una producció basada en el cost a una producció basada en la qualitat. $D$ 'aquesta manera obtindríem productes diferenciats que ens perme trien ser competitius a l'hora d'exportar i també de reduir les importacions. Per tant, amb qualitat podríem oferir productes sense que el factor preu fos tan essencial 0 , si més no, amortir l'efecte del seu augment.

- Per a poder-ho fer, seria necessari que les empreses invertissin més en I +D. Caldria canviar novament la concepció del que entenem que és primordial a l'hora de destinar recursos i considerar-ho com una inversió on les despeses d'avui generaran uns rendiments en el futur. Probablement caldran ajuts a les empreses, ja que s'ha de tenir present que el teixit empresarial espanyol se centra bàsicament en petites i mitjanes empreses on pròpiament no hi ha cap departament d'I +D i, a més, té dificultats per a invertir en aspectes com aquests (derivades, entre d'al tres, dels problemes de finançament).

- Un altre aspecte fonamental és la formació dels treballadors. Per a poder oferir qualitat és necessari invertir en formació, però aquesta ha de tenir una dimensió globalitzadora, en el sentit que ha d'anar destinada a tota la 
plantilla i no tan sols a unes categories professionals determinades. Per altra part, ha de ser una formació adequada a les necessitats detectades. $\mathrm{N} o$ es tracta de formar per formar, sinó que la formació ha de tenir uns objectius clars, concrets i predeterminats. A més, la formació no s'ha de limitar a l'àmbit empresarial, sinó que ha de comprendre els plans formatius estatals ${ }^{42}$.

Aquests canvis s'han de fer necessàriament sota una concepció global amb una implicació dels agents socials en què s'intenti aconseguir, al mateix temps, un canvi d'imatge del producte espanyol, i se sàpiga comunicar la qualitat dels nostres productes.

Si partim de la possibilitat i la idoneïtat d'una reducció de la jornada, a l'hora de determinar com s'hauria de fer, és a dir, quin procediment seria el més adient, pensem en un acord marc per a la implicació dels agents socials. Ara bé, analitzant la situació present i les postures totalment oposades entre la patronal i els sindicats més representatius, pensem que hauria de fer-se mitjançant una llei, tot i els inconvenients que comporta. Per intentar minimitzar els inconvenients (vegi's apartat sobre formes de reducció de la jornada), realitzem una proposta de com podria enfocar-se, tot i que som plenament conscients del fet que inevitablement sortirien altres problemes a l'hora de posar-se en funcionament.

Així, la llei hauria de:

- Establir un període de temps des de la seva promulgació fins a l'entrada en vigor, que permetés una adaptació a les diferències entre sectors i grandàries d'empresa. Considerem que un període de quatre anys seria suficientment ampli i no massa estès en el temps per permetre aquesta adaptació. Tot i l'establiment d'aquest període màxim, la llei també hauria de contemplar la possibilitat d'atorgar pròrrogues excepcionals als terminis marcats per alguns motius, com podria ser una eventual crisi d'un sector en concret de la producció (o una empresa, en el cas de convenis empresarials), per a la qual cosa caldria especificar quina seria la perllongació de la jornada i justificar-ne les causes (que haurien d'entrar en els supòsits marcats per la llei).

42. En referència a aquests aspectes tenim un exemple en els cursos de formació ocupacional, adreçats a aturats i a treballadors en actiu. L'objectiu d'aquests és qualificar o requalificar els treballadors per a facilitar la inserció en el mercat laboral o millorar-ne la projecció. $M$ alauradament, la seva efectivitat deixa molt a desitjar. Per a començar, la concessió d'aquests cursos depèn de l'assignació de recursos econòmics, provinents del Fons Social Europeu. A més, la planificació dels cursos no sempre es fa en funció de les necessitats detectades en el teixit empresarial de l'entorn (ja que en moltes ocasions no són ni tan sols consultats), ja que per a això es necessiten recursos tant econòmics com humans. D e fet, si la formació fos adequada a les necessitats de les empreses i de qualitat, podríem suplir alhora les possibles vacants que es generessin en determinats oficis qual ificats on actualment l'oferta ja és limitada. 
- Contemplar unes subvencions per a les empreses que creïn ocupació neta i, per tal de minimitzar els efectes negatius vers les pimes (ja que les grans empreses podrien ser les més ben eficiades per aquesta mesura en poder substituir treball per capital), pensem que hauria d'anar en funció del nombre de treballadors a l'empresa, del nombre de llocs de treball creats i del nombre d'hores reduïdes per treballador 43 .

- Preveure la necessitat de reduir o no els salaris i, en cas de considerar la reducció, la llei hauria de marcar uns trams on la reducció fos mínima o fins $\mathrm{i}$ tot nul.la, per tal que els treballadors amb rendes més baixes no fossin els més perjudicats.

La legislació, però, no es pot limitar a la reducció de la jornada, sense modificar altres aspectes directament relacionats amb la jornada, com són: regulació del treball a temps parcial, les hores extres, la distribució irregular, etc.

Cal, doncs, fer una regulació específica de les hores extraordinàries per què la reducció de la jornada no resti buida de contingut, és a dir, que no es produeixi un traspàs de les hores que es redueixen vers hores extres, tenint present, a més, la conveniència d'eliminar aquestes hores per tal de crear ocupació44. Suposant, però, que legal ment no estigués permesa la realització d'hores extraordinàries, encara podria subsistir el problema que es continuessin realitzant de manera no declarada. Per a resoldre aquest segon aspecte, seria necessari:

- Sensibilitzar patronal, sindicats i treballadors dels efectes contraproduents vers la creació d'ocupació i de la importància d'aquest objectiu45.

- Dur a terme una regulació acurada a través de conveni col-lectiu del calendari laboral, de les condicions i dels procediments de la distribució irregular de la jornada i dels mecanismes de control, compensació i sanció de les hores extraordinàries.

- D onar més significat a la inspecció de treball.

Un problema específic es troba en aquells sistemes productius que, per les peculiaritats de l'activitat i de la tecnologia, necessiten produir sense interrupció les vint-i-quatre hores del dia. N ormalment aquestes empreses organitzen el seu treball en tres torns, de vuit hores cadascun, alternant els festius. Amb una reducció a trenta-cinc hores seria necessari introduir-hi canvis, a causa dels desfasaments que generaria la mesura.

43. A títol d'exemple, veure's el $D$ ecret del $D$ epartament de Treball de la $G$ eneralitat de $C$ atalunya 248/1998 de 22 de setembre.

44. L'article 35.2 ET preveu la potestat del govern per a reduir el límit o suprimir les hores extraordinàries per a la integració dels aturats. No s'ha usat fins ara, però l'AM I, I'AN E, I'AI, I'AES, l'AIEE i molts convenis preveuen la supressió de les hores extraordinàries.

45. El problema fonamental a l'hora de sensibilitzar els treballadors es troba en el fet que en moltes ocasions els salaris són massa baixos i, per tant, l'única manera d'obtenir un salari digne a final de mesés a través de la realització de les hores extraordinàries. 


\section{Pros i contres d'alternatives possibles:}

- Torn de temps parcial: els treballadors amb aquest contracte realitzarien una jornada de tres hores/dia a fi de completar la disminució de la jornada dels treballadors a temps complet. Evidentment, aquesta alternativa és inadequada i totalment precària per al treballador. El fet de mencionar-la és degut al fet que, en ocasions, s'intenta anar per la solució més ràpida i còmoda, i alguns empresaris podrien optar per una solució com aquesta. Es podria al·legar a favor que el treballador que realitzés aquest tipus de contracte podria alhora tenir altres contractes i el propi treballador es marcaria el seu horari, però aquest fet dubtosament succeiria en coincidir els horaris requerits per part de les diferents empreses, ja que serien probablement del mateix sector d'activitat.

- Sistemes de tornsiguals als actuals amb ampliació de vacances, una opció que sembla poc lògica i viable.

- Model Volkswagen 46: aquesta empresa, en una factoria a Alemanya, va aconseguir augmentar els seus beneficis gràcies a la posada en marxa d'una setmana laboral de quatre dies i a la robotització, de manera que els treballadors realitzaven una jornada de 28,8 hores setmanals. Els empleats d'aquesta factoria dediquen el tercer dia lliure setmanal a la realització d'aficions, però també a la realització de feines en negre per compensar la retallada de salari d'un $15 \%$. Les conclusions que s'han derivat d'aquesta experiència de repartiment de l'ocupació són a grans trets: un increment d'articles de temps lliure, una disminució de vendes en el comerç al detall i un augment de problemàtiques familiars, en treballar sota pressió per por d'una nova reducció de plantilla, ja que, de fet, aquest sistema anava acompanyat de jubilacions anticipades i d'un increment notori del capital. Pel que ens afecta a nosaltres, destaquem l'aspecte de com pot afectar una mesura com aquesta la resta de l'entramat empresarial de la zona, així com l'increment de l'economia submergida.

Les diferències culturals entre els dos països són notòries i, tot i intentar de no caure en estereotips, la possibilitat que el treball en negre fos aquí molt més important seria un fet prou probable ${ }^{47}$, la qual cosa provocaria que la creació d'ocupació restés mitigada.

- Còmputs bimensuals: aquesta alternativa es basaria en grups de treball 0 persones que realitzarien una jornada diària de vuit hores amb un descans setmanal de dos dies. En arribar cada equip a la vuitena setmana realitza-

46. A tal efecte, vegin-se, entre d'altres, BOSCH, G.; LEH NDORFF, S. «La reducción de la jornada de trabajo y el empleo». A Papeles de Economía Española, núm. 72; i Z ACH ERT, UUlrich. «M edidas de creación y reparto de empleo en Alemania». A Relaciones Laborales.

47. D e fet, l'economia submergida a Espanya és molt superior que a Alemanya, tal com es pot veure en un informe de la C omissió Europea resumit a El País, 31 de març de 1998 p. 51. 
ria una setmana sencera de descans. Els inconvenients que en destacaríem estarien relacionats amb els efectes mencionats en l'apartat anterior.

- Creació d'un quart torn: aquesta alternativa combinaria la reducció de la jornada (realització de sis hores diàries) alternant els dies festius (un total de tres) cada dues setmanes. El contrapunt d'aquesta solució és que estem donant peu a més irregularitat, ja que el s festius canviarien d'una setmana a l'altra (primera setmana dos dies festius, la següent un dia, sense especificar els canvis que s'haurien de fer pel que es refereix al règim de descansos). Cal que ens preguntem fins a quin punt interessa als treballadors la reducció del nombre d'hores a canvi de més irregularitat, la qual comportaria canvis en l'organització social a un nivell probablement més elevat que no es pensa a primera vista. A favor tindríem que la reducció del nombre d'hores diàries contribuiria a reforçar aspectes de salut laboral. Tots dos aspectes són molt importants, ja que darrere de la disminució de la jornada hi ha la seva distribució, amb els efectes que té per la qualitat de vida, entenent per aquesta el temps de què disposa el treballador per gaudir d'oci, així com per poder compaginar la feina amb la convivència familiar.

Una altra opció per a reduir la desocupació, que actualment gaudeix de poc suport, és la creació d'ocupació a través del sector públic, la qual cosa s'aprofitaria per a millorar els serveis públics, realitzar tasques d'interès social ${ }^{48}$, etc. N o obstant això, aquesta opció es troba clarament limitada per la voluntat de reduir el dèficit públic i les possibles sancions de la UE a polítiques que facin créixer en excés la despesa pública.

L'objectiu de la creació d'ocupació, no pot donar-se només a través d'una reducció de la jornada (i de l'entramat que considerem que l'ha d'acompanyar), sinó que cal posar en marxa altres estratègies que mereixerien un altre estudi amb més profunditat.

\section{Bibliografia}

AA.D D . Boletín de estadísticas laborales. M adrid: M TAASS, diversos números.

AA.D D . Censos de población. M adrid: IN E, diversos exercicis.

AA.D D. Contabilidad nacional de España. M adrid: IN E, diversos exercicis.

AA.D D. Encuesta de Coyuntura Laboral. M adrid: M TAASS, diversos exercicis.

AA.D D. Encuesta de Población Activa. M adrid: IN E, diversos exercicis.

AA.DD . Índice de precios al consumo. M adrid: IN E. Sèrie de diversos exercicis. AA.D D . (1995). Lecciones de economía española, 2āed. M adrid: Cívitas.

AA.D D . (1969). M odelo economérico de política laboral (1954-1971). M adrid: Secretaria Tècnica del M inisteri de Treball.

48. Algun exemple d'això es troba en la contractació d'aturats per part de la Generalitat de C atalunya a conseqüència de l'onada d'incendis de l'estiu de 1998, com es pot veure a El Periódico de Catalunya, 10 de setembre de 1998. 
AA.D D . La negociación colectiva en las grandes empresas M adrid: M inisterio de Economía y $\mathrm{H}$ acienda, diversos anys.

AA.D D . (1995). Las relaciones laborales en España, 2a ed. M adrid: Siglo XXI.

AA.D D. Revista de E conomía y Sociología del Trabajo, núm. 15-16.

AA.D D. (1998). «T iempo de trabajo». En Alfon so M elLAd o, Carlos L. i altres (eds.).

Jornada y ordenación del tiempo de trabajo. València: Tirant lo Blanch, 1994.

Alonso Olea, M.; Casas BaAm onde, M.E. (1995). D erecho del Trabajo, 14a ed. $M$ adrid: U niversidad Complutense de $M$ adrid.

Azn AR, Guy (1994). Trabajar menos para trabajar todos. M adrid: H O AC.

BAIGES, Josep; M o lin AS, C ésar; SebASt IÁN, M iguel (1987). La economía española 1964-1985: D atos, fuentes y análisis. M adrid: Instituto de Estudios Fiscales.

Been sto ck, M ichael (ed.) (1988). International Studies in Economic M odelling Series. N ova York: Routledge.

BoSCH, G .; LEH N D ORF, S. (1997). «La reducción dela jornada de trabajo y el empleo». Papeles de Economía Española, 72.

Central de Balan Ces del Ban Co de Españ a (1997). Resultados anuales de las empresas no financieras 1996. M adrid: Banco de España.

D ORNBUSCH, Rudiger; FISCHER, Stanley (1994). M acroeconomía, 6a ed. M adrid: M CG raw-Hill.

Espin A, Álvaro; Fin A, Lluís; Lo RenTE, José Ramón (comp.) (1985). Estudios de economía del trabajo en España. Volum 1. O ferta y demanda. M adrid: M inisterio de Trabajo y Seguridad Social.

EUROSTAT (1995). Encuesta de la fuerza de trabajo. Estrasburg.

Falguera Baró, M iquel Àngel (1997). Las horas extraordinarias estructurales reflexiones sobre su origen y fines, régimen jurídico y práctica convencional. Barcelona: Centre d'Estudis i Recerca Sindicals.

G arcía G on ZÁlez, Santiago (ed.) (1996). O rígenes y causas de la crisis de competitividad. H uelva: Universidad de H uelva.

García-N IETo Paris, Juan N. «D esafíos del empleo y del trabajo». Estudis núm..?, p. 9-14.

GeNESCÀ GARRIGoSA, Enric i altres (1997). Informeanual del'empresa catalana: 1995 i Avanç 1996. Barcelona: Generalitat de Catalunya.

Grant, Robert M . (1996). D irección estratégica. Conceptos, técni cas y apli caciones. M adrid: Cívitas.

H ART, R .A. (1987). «Reducción de la jornada de trabajo: un dilema para la negociación colectiva». Col·lecció Informes O CDE, 21. M adrid: M TSS.

Jimeno SerRano, Juan Francisco (1998). «El reparto del trabajo y la creación de empleo». Boletín IPC de Análisis M acroeconómico.

M artín Valverde, Antonio i altres (1997). Derecho del Trabajo, 6a ed. M adrid: Tecnos. M cConnell, Cam pbell R.; Brue, Stanley L. (1997). Economía laboral. M adrid: M CG raw-H ill.

M ontoya Melgar, A. (1996). Derecho del Trabajo, 17ạ ed. Madrid: Tecnos.

M ON TOYA M ELGAR, A. (1992). I deología y lenguaje en las leyes laborales de España (1873-1978), 1a ed. M adrid: Cívitas.

M UÑ OZ CIDAD, Cándido (1994). Las cuentas de la nación. Nueva introducción a la economía aplicada. M adrid: Cívitas.

Palomeque López, M.; Álvarez de la Rosa, M. (1996). Derecho del Trabajo, 4a ed.

$M$ adrid: Ceura. 
Paran Que, R. (1969). La semana de treinta horas. M adrid: Colección Beta.

Pulid o, Antonio (1989). M odelosE conométricos. M adrid: Pirámide.

RECIO, Albert (1999). «Sindicatos, globalización económica y crisis ambiental». Papers, 58. Bellaterra: UAB.

RECIO, Eugenio M . (1998). «U na nova estratègia per a lluitar contra l'atur». Tracte, febrer de 1998, p. 15.

RIECH M AN N, Jorge; ReCIO, Albert (1997). Q uien parte y reparte... : El debate sobre la reducción del tiempo de trabajo. Col·lecció M ás madera, 14, Barcelona: Icaria.

Sala Fran co, T.; Albiol M ontesin os, I. (1996). Derecho Sindical, 4ạ ed. València: Tirant lo Blanch.

Sala Franco, T. i altres (1996). Derecho del Trabajo, 10a ed. València: Tirant lo Blanch. T AM AM ES, Ramón (1992). Estructura Económica de España, 22aํed. M adrid: Alianza. W HITE, M ichael (1989). «Reducción de la jornada de trabajo: posibilidades y perspectivas». C ol·lecció Informes O IT, 17. M adrid. M inisterio de Trabajo y Seguridad Social.

W yplosz, Charles; BuRdA, M ichael C. (1994). M acroeconomía: un texto europeo. Barcelona: Ariel. 